\title{
Recovery of ammonia and phosphate minerals from swine wastewater using gas-permeable membranes
}

\author{
M.B. Vanotti ${ }^{a}{ }^{\star}$, P.J. Dube ${ }^{a}$, A.A. Szogi ${ }^{a}$, M.C. García-González ${ }^{b}$ \\ aUnited States Department of Agriculture, Agricultural Research Service, Coastal \\ Plains Soil, Water and Plant Research Center, 2611 W. Lucas St, Florence, South \\ Carolina 29501, USA \\ ${ }^{\mathrm{b}}$ Agriculture Technological Institute of Castilla and Leon (ITACyL), Valladolid, \\ Spain
}

*Corresponding author. Tel: +1-843-669-5203 ext. 108.

E-mail address: matias.vanotti@ars.usda.gov (M.B. Vanotti)

\section{Abstract}


Gas-permeable membrane technology is useful to recover ammonia $\left(\mathrm{NH}_{3}\right)$ from liquid manures. In this study, phosphorus $(\mathrm{P})$ recovery via $\mathrm{MgCl}_{2}$ precipitation was enhanced by combining it with $\mathrm{NH}_{3}$ recovery through gas-permeable membranes. Anaerobically digested swine wastewater containing approximately $2300 \mathrm{mg} \mathrm{NH}_{4}{ }^{+}-$ $\mathrm{N} \mathrm{L}^{-1}$ and $450 \mathrm{mg} \mathrm{P} \mathrm{L}^{-1}$ was treated using submerged membranes plus low-rate aeration to recover the $\mathrm{NH}_{3}$ from within the liquid and $\mathrm{MgCl}_{2}$ to precipitate the $\mathrm{P}$. The experiments included a first configuration where $\mathrm{N}$ and $\mathrm{P}$ were recovered sequentially and a second configuration with simultaneous recovery. The low-rate aeration reduced the natural carbonate, increased $\mathrm{pH}$ and accelerated $\mathrm{NH}_{3}$ uptake by the gas-permeable membrane system, which in turn benefited $\mathrm{P}$ recovery. Phosphorus removal efficiency was $>90 \%$ and $\mathrm{P}$ recovery efficiency was about $100 \%$. With higher $\mathrm{NH}_{3}$ capture, the recovered $\mathrm{P}$ contained higher $\mathrm{P}_{2} \mathrm{O}_{5}$ content (37-46\%, > 98\% available), similar to the composition of the biomineral newberyite $\left(\mathrm{MgHPO}_{4} \cdot 3 \mathrm{H}_{2} \mathrm{O}\right)$.

Keywords. Livestock wastewater, nutrient recovery, ammonia recovery, gaspermeable membranes, phosphorus recovery, newberyite 


\section{Introduction}

Conservation and recovery of nitrogen $(\mathrm{N})$ and phosphorus $(\mathrm{P})$ from livestock, industrial and municipal wastes is important because of economic and environmental reasons. More sustainable techniques using $\mathrm{P}$ recovery for both solid and liquid waste are important to close the P cycle in modern human society and address future scarcity (Desmidt et al., 2015; Keyzer, 2010). In the United States, the largest source of ammonia $\left(\mathrm{NH}_{3}\right)$ emissions is livestock farming, contributing 2.5 million tons/year (EPA, 2014). In addition, P build up in soils to excessively high levels due to animal manures often results in eutrophication and pollution of surface waters (Kleinman et al., 2015). Therefore, the removal and recovery of $\mathrm{N}$ and $\mathrm{P}$ is a desirable feature for new treatment technology for livestock effluents because the nutrients can be exported off the farm, which could solve the problems of $\mathrm{N}$ and $\mathrm{P}$ surpluses in concentrated livestock production, substitute for commercial fertilizers, help close the P cycle, and create new businesses (Keyzer, 2010, Szogi et al., 2015, Vanotti et al. 2009).

Technologies for recovery and reuse of $\mathrm{P}$ from livestock effluents and also municipal effluents have focused mostly on struvite $\left(\mathrm{MgNH}_{4} \mathrm{PO}_{4} \cdot 6 \mathrm{H}_{2} \mathrm{O}\right)$ precipitation (Burns et al., 2001; Desmidt et al, 2015; Karunanithi et al., 2015; Nelson et al., 2003). Struvite forms from 1:1:1 ratios of magnesium $\left(\mathrm{Mg}^{2+}\right)$, ammonium $\left(\mathrm{NH}_{4}{ }^{+}\right)$and phosphate $\left(\mathrm{PO}_{4}{ }^{3-}\right)$. Addition of $\mathrm{MgCl}_{2}$ and $\mathrm{NaOH}$ (Burns et al, 2001; Nelson et al, 2003; Westerman et al., 2008) have been used to balance $\mathrm{Mg}^{2+}$ to $\mathrm{PO}_{4}{ }^{3-}$ ratio, increase $\mathrm{pH}$, and improve process efficiency. Although the 
process also recovers $\mathrm{N}$, in livestock wastewater only about $<15 \%$ of the $\mathrm{N}$ contained in the influent could potentially be recovered through struvite because of the very high $\mathrm{NH}_{4}{ }^{+}$to $\mathrm{PO}_{4}{ }^{3}$ - ratio in these effluents (i.e. 7.6:1 to $17.0: 1$, Burns et al., 2001), unless external phosphates are added to balance the $\mathrm{NH}_{4}{ }^{+}$(Liberty et al., 1986). Another way to recover $P$ is through calcium phosphate precipitation with $\mathrm{Ca}(\mathrm{OH})_{2}$ at $\mathrm{pH}>9$. Vanotti et al. (2005) used a biological nitrification step to eliminate the carbonate interference in swine wastewater before precipitating calcium phosphate with lime. Hao et al. (2013) indicated that future efforts should go to develop technologies based on other phosphate-based compound: any acceptable form of phosphate by the fertilizer industry as long as it contains appropriate $\mathrm{P}_{2} \mathrm{O}_{5}$ content (30-40\% favoured).

New technologies for $\mathrm{NH}_{3}$ abatement in livestock operations are being focussed on $\mathrm{N}$ recovery. These technologies include: 1) reverse osmosis using high pressure and hydrophilic membranes (Massé et al., 2010; Thorneby et al., 1999); 2) nanofiltration (Kertesz et al., 2010); 3) air-stripping using stripping towers and acid absorption (Bonmatí and Flotats, 2003; Liao et al., 1995); 4) zeolite adsorption through ion exchange (Milan et al., 1997); 5) co-precipitation with phosphate and magnesium to form struvites (Nelson et al., 2003; Uludag-Demirer et al., 2005); and 6) a new process using gas-permeable membranes at low pressure (Vanotti and Szogi, 2015; Garcia-Gonzalez and Vanotti, 2015). Zarebska et al. (2015) reviewed the pros and cons of all these $\mathrm{N}$ recovery methods and indicated the energy consumption for the gas-permeable membrane process 
was among the lowest $\left(0.18 \mathrm{~kW} \mathrm{~h} \mathrm{~kg} \mathrm{NH}_{3}{ }^{-1}\right)$. However, its main drawback was the cost of alkali chemicals to increase manure pH (Zarebska et al., 2015).

The gas-permeable membrane process includes the passage of gaseous $\mathrm{NH}_{3}$ through a microporous, hydrophobic membrane, and capture and concentration in a stripping solution on the other side of the membrane. The membrane manifolds are submerged in the liquid and the $\mathrm{NH}_{3}$ is removed from the liquid before it escapes into the air (Vanotti and Szogi, 2015); the $\mathrm{NH}_{3}$ permeates through the membrane pores reaching the acidic solution located on the other side of the membrane. Once in the acidic solution, $\mathrm{NH}_{3}$ combines with free protons to form non-volatile ammonium $\left(\mathrm{NH}_{4}^{+}\right)$ions that are converted into a valuable $\mathrm{NH}_{4}{ }^{+}$ salt fertilizer, which is desirable to export $\mathrm{N}$ off the farm to other regions where $\mathrm{N}$ is needed.

Gas-permeable membranes have been shown to effectively recover more than $97 \%$ of $\mathrm{NH}_{4}{ }^{+}$from raw and anaerobically digested swine wastewater (GarciaGonzalez and Vanotti, 2015; Dube et al., 2016; Garcia-Gonzalez et al., 2015). The process is responsive to increased $\mathrm{pH}$ through addition of alkali chemicals, which leads to an increased release of $\mathrm{NH}_{3}$ from the manure and capture by the membrane. A strategy to reduce costs of this $\mathrm{N}$ recovery process and facilitate its adoption by farmers is to use simple and inexpensive alternatives for raising the $\mathrm{pH}$ of the manure in a farm setting. Vanotti and Szogi (2015) proposed the use of gaspermeable membranes with low-rate aeration and nitrification inhibitors to enhance the recovery of $\mathrm{NH}_{3}$ without alkali and reduce costs. Such conditions applied to 
stored livestock effluents resulted in a pH increase of about 1 unit and increased $\mathrm{NH}_{3}$ release. For the purpose of the enhancement of the recovery of $\mathrm{NH}_{3} \mathrm{~N}$ recovery using gas-permeable membranes, the term "low-rate aeration" was defined as an aeration rate that is less than about $5 \%$ of the aeration rate used for biological ammonia removal/nitrification (Vanotti et al., 2016). Using the aeration approach, Dube et al. (2016) increased the $\mathrm{pH}$ of swine wastewater to 9.2 without alkali chemicals and obtained $\mathrm{NH}_{4}{ }^{+}$recovery efficiencies of $96-98 \%$ while reducing costs of treatment by $70 \%$. The annualized of $\mathrm{NH}_{4}{ }^{+}$recovery from a 4000 -head swine farm with anaerobic digester (12,547 kg N/year) using gas-permeable membranes with low-rate aeration and nitrification inhibitors was calculated at $\$ 37,926 /$ year: $55.5 \%$ for equipment, $37.1 \%$ for acid ( $120 \mathrm{~kg} \mathrm{H}_{2} \mathrm{SO}_{4} /$ day), $4.7 \%$ for nitrification inhibitor $(0.5 \mathrm{~kg} / \mathrm{d})$, and $2.7 \%$ electrical cost $(40.1 \mathrm{~kW} \mathrm{~h} / \mathrm{d}$ for power use of blower and pumps) (Dube et al., 2016). Garcia-Gonzalez et al (2015) compared the operational cost of using alkali $(\mathrm{NaOH})$ vs. low-rate aeration (power and inhibitor) to increase manure $\mathrm{pH}$ and optimize $\mathrm{N}$ recovery using gaspermeable membranes. Relative to alkali addition, the aeration approach reduced the costs of $\mathrm{NH}_{4}{ }^{+}$recovery by $57 \%$. Alkalinity is readily consumed in this system (72 to $73 \%$ reduction). The $\mathrm{N}$ recovery process produces wastewater with higher $\mathrm{pH}$, lower $\mathrm{NH}_{4}{ }^{+}$concentration and lower carbonate alkalinity (Dube et al., 2016), which are modified conditions that could promote $\mathrm{P}$ recovery using precipitation processes (Desmidt et al., 2015; Liu et al., 2015; Nelson et al., 2003; Vanotti et al., 2003). 
We hypothesized that, by implementing P precipitation in combination with the membrane $\mathrm{N}$ recovery system, the phosphorus recovery could also benefit. The objective of this study was to evaluate the potential advantages and technical feasibility of simultaneous $\mathrm{N}$ and $\mathrm{P}$ recovery suitable for digester effluents. It combines a gas-permeable membrane technology ( $\mathrm{N}$ recovery) with $\mathrm{P}$ recovery of solid products by precipitation. The $\mathrm{P}$ precipitating agent selected was $\mathrm{MgCl}_{2}$ with or without alkali supplements.

\section{Materials and Methods}

\subsection{Basic process configuration}

The basic configuration of the process evaluated in the experiments is shown in Fig. 1 (Vanotti et al., 2016). The overall goal was to synchronize the recovery of phosphorus $(\mathrm{P})$ via chemical precipitation with the recovery of $\mathrm{NH}_{3}$ through gas-permeable membranes and low-rate aeration by taking advantage of the increased $\mathrm{pH}$ and alkalinity destruction during the $\mathrm{N}$ recovery. Ammonia from anaerobically digested swine effluent was extracted in an ammonia-separation tank using a submerged gas-permeable membrane module and its was recovered in a stripping acid solution reservoir/nitrogen concentration tank. Low-rate aeration was provided in the ammonia separation tank to increase $\mathrm{pH}$ and the ammonium $\left(\mathrm{NH}_{4}{ }^{+}\right)$ recovery rate (Dube et al., 2016). A phosphorus recovery tank separated precipitated phosphorus. The two configurations evaluated in this work used the same $\mathrm{NH}_{3}$ recovery system but varied in the location where the $\mathrm{P}$ precipitating 
agents were added. In the first configuration (experiment 1), the $\mathrm{P}$ precipitating agents $\left(\mathrm{MgCl}_{2}\right.$ with or without $\left.\mathrm{NaOH}\right)$ were added to the liquid after $\mathrm{NH}_{4}{ }^{+}$was substantially removed. In the second configuration (experiment 2 ), the same $P$ precipitating agents were added into the ammonia-separation tank at the start of $\mathrm{N}$ separation with the liquid containing high $\mathrm{NH}_{4}{ }^{+}$concentration. The two experiments were done under laboratory conditions.

\section{[Figure 1]}

\subsection{Ammonia separation reactor}

The $\mathrm{NH}_{3}$ recovery portion of the study was done using the ammoniaseparation reactor and protocol of Dube et al., 2016 (Fig. A.1). It consisted of a 2-L aerated ammonia-separation tank with an effective liquid manure volume of $1.5 \mathrm{~L}$ fitted with a submerged gas-permeable membrane connected with a stripping solution reservoir containing $0.25 \mathrm{~L}$ diluted $1 \mathrm{~N}$ sulfuric acid (stripping solution). The acid solution was continuously recirculated at $4 \mathrm{~mL} \mathrm{~min}^{-1}$ through the inside of the tubular membrane located in the ammonia-separation tank using a peristaltic pump (Cole-Parmer, Masterflex L/S Digital Drive, Illinois, USA). The tubular membrane was anchored to a glass rod inside the vessel to ensure submersion in the liquid manure. The tubular membrane was made of e-PTFE material (Phillips Scientific, Inc., Rock Hill, SC) with a length of $60 \mathrm{~cm}$, outer diameter of $10.25 \mathrm{~mm}$, and wall thickness of $0.75 \mathrm{~mm}$. It had an average pore size of $2.5 \mu \mathrm{m}$ and bubble point of $210 \mathrm{kPa}$. Bubble point was determined as the minimum pressure required to force air through the membrane which has been prewet with isopropylalcohol 
(ASTM, 2011). The ratio of the tubular membrane length per manure volume was $0.04 \mathrm{~cm} \mathrm{~cm}^{-3}$ and the ratio of e-PTFE membrane area per length was $0.0323 \mathrm{~m}^{2} \mathrm{~m}^{-}$

${ }^{1}$. Low-rate aeration was delivered to the bottom of the ammonia-separation tank at a rate of $0.12 \mathrm{~L}$-air L-manure ${ }^{-1} \mathrm{~min}^{-1}$ using an aquarium air pump, a shielded air flow meter with a precision valve (GF-9260, Gilmont Instruments, Illinois, USA) and an aquarium diffuser stone that provided fine bubbles. The lid of the ammoniaseparation tank was not sealed; it had one open port that allowed the air to escape. Nitrification inhibitor N-Serve (TCMP - 2-chloro-6 trichloromethyl pyridine, Hach, Loveland, CO, USA) was added to the manure at a rate of $22.5 \mathrm{mg} \mathrm{L}^{-1}$ dosage to ensure nitrification inhibition (Dube et al., 2016). Small volume wastewater samples $(2 \mathrm{~mL})$ were drawn daily from the ammonia separation tank to test for alkalinity and $\mathrm{NH}_{4}{ }^{+}$concentration. Samples from the stripping solution $(0.2 \mathrm{~mL})$ were also taken daily and tested for $\mathrm{NH}_{4}{ }^{+}$. The $\mathrm{pH}$ was measured daily directly in the wastewater and stripping solution. Concentrated sulfuric acid was added to the stripping acid solution reservoir as needed to an end-point $\mathrm{pH}$ of about 1 when the $\mathrm{pH}$ of the stripping solution increased above about 2 as result of active $\mathrm{NH}_{3}$ capture $\left(\mathrm{NH}_{3}+\mathrm{H}^{+} \rightarrow \mathrm{NH}_{4}^{+}\right)$.

\subsection{Phosphorus separation in experiment 1 (Configuration 1)}

In this experiment, $\mathrm{NH}_{3}$ was substantially removed from wastewater (about $70 \%$ ) with the gas-permeable membrane process in a first step. In a second step, P precipitating agents were added to the $\mathrm{N}$ treated effluent in the phosphorusrecovery tank (Figure 1). The effluent from the ammonia-separation tank after 2 
days of treatment was transferred to a 2-L phosphorus separation tank where it was mixed with magnesium chloride $\left(\mathrm{MgCl}_{2}\right)$ with or without $\mathrm{NaOH}$ to obtain $\mathrm{P}$ precipitate. The chemical used was $\mathrm{MgCl}_{2} \cdot 6 \mathrm{H}_{2} \mathrm{O}$ (CAS 7791-18-6, Sigma Aldrich, St. Louis, MO). In both treatments, the rate of $\mathrm{Mg}$ applied was $16.4 \mathrm{mmol} \mathrm{L}^{-1}(3.34$ $\left.\mathrm{mg} \mathrm{MgCl} 2 \cdot 6 \mathrm{H}_{2} \mathrm{O} \mathrm{L}^{-1}\right)$. This rate was based on the initial total $\mathrm{P}$ concentration in the wastewater (about $430 \mathrm{mg} \mathrm{L}^{-1}$ ) and a Mg:P molar ratio setting of about 1.2:1. In the second treatment (with $\mathrm{NaOH}$ ), the phosphorus recovery tank received approximately $10 \mathrm{mmol} \mathrm{NaOH}$ after the addition of $\mathrm{MgCl}_{2}$ to increase the $\mathrm{pH}$ to 9.2 . The chemicals were reacted with the effluent by mixing with a stirrer for about one minute. After about a 0.5 hours gravity sedimentation period, the supernatant (treated effluent, Fig. 1) was decanted using a peristaltic pump, sampled and analyzed for total $\mathrm{P}, \mathrm{NH}_{4}{ }^{+}, \mathrm{TKN}$, and alkalinity. The $\mathrm{P}$ precipitate sludge was further dewatered using glass fiber filters and washed with small portions of distilled water in fine stream until filtrate measured about three times the initial wet sludge volume. Solids were dried at $40{ }^{\circ} \mathrm{C}$ in a forced-air drier and characterized for dry weight, total $\mathrm{N}, \mathrm{NH}_{4}{ }^{+}, \mathrm{TKN}, \mathrm{P}, \mathrm{Mg}, \mathrm{Ca}$, and $\mathrm{K}$ and citrate soluble $\mathrm{P}$ (plant available $\mathrm{P})$. Mass balances were conducted to calculate recoveries of $\mathrm{N}$ and $\mathrm{P}$ by measuring flows and concentrations in the inflow and the three outputs of the system in Fig. 1. All experiments were duplicated. The entire process was performed at room temperature of approximately 25 degrees $\mathrm{C}$.

\subsection{Phosphorus separation in experiment 2 (Configuration 2)}

In this configuration, the $\mathrm{P}$ precipitating agents $\left(\mathrm{MgCl}_{2}\right.$ with or without 
$\mathrm{NaOH}$ ) were added first to the digester effluent in the ammonia-separation tank containing high-ammonia concentration (Fig. 1). In this example, the ammoniaseparation tank also acts as a $\mathrm{P}$ reaction tank. There were three chemical treatment combinations. One treatment received only $\mathrm{MgCl}_{2}$ addition at $16.4 \mathrm{mmol}$ $\mathrm{L}^{-1}$. Another treatment received $\mathrm{MgCl}_{2}$ in the same dosage and a small amount of alkali, approximately $3 \mathrm{mmol} \mathrm{L}^{-1}$ of $\mathrm{NaOH}$, to adjust the $\mathrm{pH}$ to 8.2 . The third treatment received $\mathrm{MgCl}_{2}$ in the same dosage and a larger amount of alkali, 117 $\mathrm{mmol} / \mathrm{L} \mathrm{NaOH}$, to reach $\mathrm{pH}$ 9.2. The $\mathrm{MgCl}_{2}$ was added first to the wastewater and then $\mathrm{NaOH}$ was added in the second and third treatment while mixing with a stirrer and monitoring $\mathrm{pH}$. The wastewater with mixed chemicals was reacted in the ammonia/phosphorus-separation tank. Low-rate aeration was used in the ammonia-separation tank as described before to increase process $\mathrm{pH}$ and enhance the capture and recovery of the $\mathrm{NH}_{3}$ and the formation of $\mathrm{P}$ solids at the higher $\mathrm{pH}$ created by aeration. The process was completed at the end of the $\mathrm{NH}_{3}$ extraction when $>90 \%$ of the $\mathrm{NH}_{4}{ }^{+}$was removed from the manure. The treatment time for the swine anaerobic digester effluents containing approximately $2,400 \mathrm{mg}$ $\mathrm{NH}_{3} / \mathrm{L}$ was approximately 5 to 6 days. At that time, all the $\mathrm{P}$ was in solid form and precipitated. The mixed liquid and solids was transferred to a settling vessel. After about 0.5 hour gravity sedimentation period, the supernatant (treated water, Fig. 1) was decanted, sampled and analyzed for total $\mathrm{P}, \mathrm{NH}_{4}{ }^{+}, \mathrm{TKN}$, and alkalinity. The $\mathrm{P}$ precipitate was dewatered and characterized in the same manner as experiment 1. Mass balances were conducted to calculate recoveries of $\mathrm{N}$ and $\mathrm{P}$ by measuring flows and concentrations in the inflow and the outputs of the system. All 
experiments were duplicated. The entire process was performed at room temperature of approximately 25 degrees $\mathrm{C}$.

\subsection{Analytical Methods}

Alkalinity was determined with an automatic titrator (TitroLine easy, Schott Instruments) by measuring the amount of $0.01 \mathrm{~N}$ hydrochloric acid required to reach an end-point $\mathrm{pH}$ of 4.5 and was reported as $\mathrm{mg} \mathrm{CaCO}_{3} \mathrm{~L}^{-1}$ (total alkalinity, Standard Methods $2320 \mathrm{~B}$ ). The $\mathrm{pH}$ was monitored using a pH meter (Orion Star A111, Thermo Scientific). Determination of total solids (TS), volatile solids (VS), chemical oxygen demand (COD), total Kjeldahl nitrogen (TKN), ammonium $\left(\mathrm{NH}_{4}{ }^{+}\right)$, nitrate- $\mathrm{N}$, total phosphorus $(\mathrm{P})$ and phosphate- $\mathrm{P}$ in the liquid manure samples were performed using the APHA Standard Methods (1998). Total solids (TS) were determined after sample drying to constant weight at $105^{\circ} \mathrm{C}$ and volatile solids (VS) were determined after further ignition in a muffle furnace at $500{ }^{\circ} \mathrm{C}$ for $15 \mathrm{~min}$ (Standard Methods $2540 \mathrm{~B}$ and $2540 \mathrm{E}$, respectively). Chemical oxygen demand (COD) was determined through the closed reflux colorimetric method (Standard Method $5220 \mathrm{D}$ ). The $\mathrm{NH}_{4}{ }^{+}$analysis was done by colorimetry (Technicon Instruments Corp., 1997, Standard Method 4500- $\mathrm{NH}_{3} \mathrm{G}$ ). Phosphate-P was determined with the automated ascorbic acid method (Standard Method 4500-P F) and nitrate- $\mathrm{N}$ by the automated Cd reduction method (Standard Method $4500-\mathrm{NO}_{3}{ }^{-}$ $\mathrm{F})$. The total phosphorus (P), Calcium (Ca), Mg (magnesium), and potassium (K) concentrations in the liquid were determined using nitric acid digestion with peroxide (EPA 3050B) using a block digester (Peters, 2003) and inductively 
coupled plasma (ICP) analysis (Standard Method 3125). For the recovered phosphorus solids, N was determined using TKN acid digestion (Gallaher et al., 1976) and the salicilate method (Standard Method 4500-Norg D) adapted to digested extracts (Technicon Instruments Corp., 1977). The P content in the recovered phosphorus solids was determined using $\mathrm{HCl}$ acid extraction (Vanotti et al., 2003). For the $\mathrm{HCl}$ extraction, $5 \mathrm{~mL}$ of $1 \mathrm{~N} \mathrm{HCl}$ was added to $100 \mathrm{mg}$ of dry precipitate in a test tube, vortexed for $1 \mathrm{~min}$, and allowed to sit for $1 \mathrm{~h}$. The extract was diluted to $75 \mathrm{~mL}$ with distilled water and analyzed using ICP analysis. The K, $\mathrm{Ca}$ and $\mathrm{Mg}$ concentrations were also measured in the $\mathrm{HCl}$ extract using ICP. Citrate-insoluble P and plant available P (citrate-insoluble P subtracted from total P) were determined according to AOAC Official Methods 963.03 and 960.02 (AOAC International, 2000). Data results were analyzed by means and standard deviation. Removal and recovery efficiencies of $\mathrm{P}$ and $\mathrm{N}$ were determined using mass balances that considered the manure liquid volume and $P$ and $N$ concentrations before and after treatment as well as in the mass of $\mathrm{N}$ and $\mathrm{P}$ in recovered phosphorus solids and the $\mathrm{N}$ concentration tank.

\subsection{Origin of manure}

Liquid swine manure was collected from a source of anaerobic digester supernatant effluent in North Carolina, USA. The manure was collected from the supernatant effluent of covered anaerobic lagoons on a swine finishing farm growing pigs from 22.7 to $100 \mathrm{~kg}$. Three $15-\mathrm{L}$ plastic containers were filled using a 
pump, transported to USDA-ARS laboratory in Florence, SC and stored at $4^{\circ} \mathrm{C}$ until used. The stored liquid manure was thoroughly mixed before use in the experiments. The digested liquid manure contained, on average, $\mathrm{pH} 8.36$, alkalinity $11.4 \mathrm{~g} \mathrm{~L}^{-1}$, TS $8.5 \mathrm{~g} \mathrm{~L}^{-1}$, VS $1.5 \mathrm{~g} \mathrm{~L}^{-1}$, COD $1700 \mathrm{mg} \mathrm{L}^{-1}$, TKN $2460 \mathrm{mg} \mathrm{L}^{-1}$, $\mathrm{NH}_{4}-\mathrm{N} 2330 \mathrm{mg} \mathrm{L}^{-1}$, nitrate-N $0 \mathrm{mg} \mathrm{L}^{-1}, \mathrm{~K}^{2} 2300 \mathrm{mg} \mathrm{L}^{-1}, \mathrm{P} 446 \mathrm{mg} \mathrm{L}^{-1}$, phosphate-P $363 \mathrm{mg} \mathrm{L}^{-1}$, Ca $63.8 \mathrm{mg} \mathrm{L}^{-1}$, Mg $10.3 \mathrm{mg} \mathrm{L}^{-1}$, Fe $3.26 \mathrm{mg} \mathrm{L}^{-1}$, Al $1.28 \mathrm{mg} \mathrm{L}^{-1}$, Cu $1.35 \mathrm{mg} \mathrm{L}^{-1}$, and $\mathrm{Zn} 1.14 \mathrm{mg} \mathrm{L}^{-1}$.

\section{Results and discussion}

\subsection{Experiment 1}

In this experiment, the initial goal was to remove approximately $70 \%$ of the $\mathrm{NH}_{4}{ }^{+}$from the digester supernatant wastewater (containing $2300 \mathrm{mg} \mathrm{NH}{ }_{4}-\mathrm{N} / \mathrm{L}$ ) in the ammonia separation tank in a first step, and then apply $\mathrm{MgCl}_{2}$ in a second step to precipitate the $\mathrm{P}$ under conditions of reduced $\mathrm{NH}_{4}{ }^{+}$concentrations (Configuration 1, Fig. 1 and Table 1). The ammonia separation tank with gas-permeable membrane module and aeration was operated in a batch process. The $\mathrm{NH}_{4}^{+}$ concentration in the manure was monitored daily and the target level of removal of $70 \%$ was reached at about two days of treatment (Fig. 2). At that time, the $\mathrm{N}$ recovery process was stopped and the liquid was transferred to the P recovery tank. During the 2-day $\mathrm{N}$ recovery period, $\mathrm{NH}_{4}{ }^{+}$concentration in the wastewater was reduced from an initial $2300 \pm 110 \mathrm{mg} \mathrm{N} \mathrm{L}^{-1}$ to $696 \pm 56 \mathrm{mg} \mathrm{N} \mathrm{L}^{-1}$. At the same time, the $\mathrm{NH}_{4}{ }^{+}$concentration in the stripping solution increased linearly from 0 to 
$9,580 \pm 778 \mathrm{mg} \mathrm{N} \mathrm{L}^{-1}$ (Fig. 2), about 4 times the concentration of the influent manure. The $\mathrm{NH}_{4}{ }^{+}$recovery efficiency obtained in the ammonia-separation tank was $99.9 \%$ (Table 1).

[Figure 2]

Since the removal of $\mathrm{NH}_{3}$ by the gas-permeable membrane increases the acidity in the liquid manure as represented in Eq. 1 (Dube et al., 2016), an increased $\mathrm{pH}$ is needed for efficient $\mathrm{N}$ uptake by the gas-permeable process (Garcia-Gonzalez and Vanotti, 2015).

$$
\mathrm{NH}_{4}{ }^{+} \rightarrow \mathrm{NH}_{3}+\mathrm{H}^{+}
$$

Low-rate aeration was an effective approach to increase the $\mathrm{pH}$ of the manure and achieve high $\mathrm{N}$ recovery efficiency without chemicals consistent with Dube et al. (2016) and Garcia-Gonzalez et al. (2015). Garcia-Gonzalez et al. (2015) showed that the positive effect of the low-rate aeration on the $\mathrm{NH}_{4}{ }^{+}$recovery rate by the gas-permeable membrane process was equivalent to adding $2.14 \mathrm{~g}$ $\mathrm{NaOH}$ per $\mathrm{L}$ of manure. Dube et al (2016) showed that the low-rate aeration resulted in a higher $\mathrm{pH}$ along with 5 to 6 times as fast recovery compared to the same system without aeration. During aeration of the manure, carbonate alkalinity is consumed and $\mathrm{OH}^{-}$is instantly released, subsequently raising the $\mathrm{pH}$ of the manure according to Eq. 2 and enhancing both the formation of $\mathrm{NH}_{3}$ as defined in Eq. 3 and the $\mathrm{NH}_{3}$ uptake via the gas-permeable membrane.

$$
\mathrm{HCO}_{3}^{-}+\text {air } \rightarrow \mathrm{OH}^{-}+\mathrm{CO}_{2}
$$




$$
\mathrm{NH}_{4}{ }^{+}+\mathrm{OH}^{-} \rightarrow \mathrm{NH}_{3}+\mathrm{H}_{2} \mathrm{O}
$$

During the 2-day $\mathrm{N}$ recovery period with low-rate aeration, the $\mathrm{pH}$ of the manure increased about one unit, from $8.36 \pm 0.01$ to $9.38 \pm 0.06$, and the total alkalinity concentration was reduced from $11,400 \pm 35 \mathrm{mg} \mathrm{L}^{-1}$ to $6,230 \pm 239 \mathrm{mg} \mathrm{N} \mathrm{L}^{-}$ ${ }^{1}$ (Table 1).

Higher $\mathrm{pH}$, lower carbonate alkalinity and reduced $\mathrm{NH}_{4}{ }^{+}$are modified conditions in livestock wastewater that enhance precipitation of phosphates with alkaline earth metal precipitating compounds (Vanotti el al., 2005). In this experiment, those conditions were attained. The effluent after $\mathrm{NH}_{3}$ treatment had a high $\mathrm{pH}$ of approximately 9.38 as a result of $\mathrm{CO}_{2}$ stripping (Eq. 2), and a lower alkalinity by the removal of $\mathrm{NH}_{3}$ thru the membrane and release of hydrogen ions (Eq. 1). The high $\mathrm{pH}$ was sufficient to effectively precipitate the $\mathrm{P}$ with $\mathrm{MgCl}_{2}$ without need of alkali $(\mathrm{NaOH})$ addition (Table 1). After rapid mixing with the $\mathrm{MgCl}_{2} \cdot 6 \mathrm{H}_{2} \mathrm{O}$, the phosphorus quickly precipitated as a solid. Precipitate flocs were visible. The efficiencies of $\mathrm{P}$ removal obtained using $\mathrm{MgCl}_{2}$ were high in both the treatment without alkali addition and the treatment with $\mathrm{NaOH}$ addition: 95 and 97\% (Table 1). Corresponding $P$ recovery efficiencies (how much of the $P$ removed from wastewater was recovered) were also high: 99 and $97 \%$. Therefore, alkali addition was not needed to precipitate the $\mathrm{P}$ with $\mathrm{MgCl}_{2}$. Mass balances of the recovery of $\mathrm{N}$ and $\mathrm{P}$ are shown in Table 2. Using configuration 1, the $\mathrm{N}$ that was recovered (about $71 \%$ ) was mostly recovered by the gas-permeable membrane and little (1.5\%-1.6\%) of the $\mathrm{N}$ was recovered in the solid precipitate. 
For $\mathrm{P}$, configuration 1 recovered $94 \%$ of the $\mathrm{P}$. The unaccounted $\mathrm{N}$ and $\mathrm{P}$ were generally low $(<5.5 \%)$. Overall, results of nutrient recovery obtained with configuration 1 indicate that efficient $\mathrm{N}$ and $\mathrm{P}$ recovery can be obtained using the gas-permeable system and subsequent $\mathrm{P}$ precipitation with alkaline earth metal compounds, in this case $\mathrm{MgCl}_{2}$. Low-rate aeration had the double benefit that substituted for alkali chemical addition twice: during capture of $\mathrm{NH}_{3}$ with the membrane system and during the precipitation of Mg phosphates.

\subsection{Experiment 2}

In this experiment, the $\mathrm{P}$ precipitating agents $\left(\mathrm{MgCl}_{2}\right.$ alone or with $\left.\mathrm{NaOH}\right)$ were added first in the ammonia-separation tank to the digester supernatant effluent containing high-ammonia concentration (Configuration 2, Fig. 1). In this example, the ammonia separation tank also acts as a $\mathrm{P}$ reaction tank and the precipitation of $\mathrm{P}$ with $\mathrm{Mg}$ occurs with higher $\mathrm{NH}_{4}{ }^{+}$concentrations present. The initial $\mathrm{pH}$ of wastewater was $8.36 \pm 0.01$. After $\mathrm{MgCl}_{2}$ addition, it decreased to 7.87 \pm 0.01 . In the treatment with only $\mathrm{MgCl}_{2}$ addition, the $\mathrm{pH}$ increased after aeration over one day to $9.47 \pm 0.01$ when the $P$ was being reacted and precipitated and the $\mathrm{NH}_{3}$ extracted, simultaneously (Table 3). In the treatments with $\mathrm{MgCl}_{2}$ plus addition of alkali to a target $\mathrm{pH} 8.2\left(2.7 \mathrm{mmol} \mathrm{NaOH} \mathrm{L}^{-1}\right)$ and $9.2(117 \mathrm{mmol} \mathrm{NaOH}$ $\left.\mathrm{L}^{-1}\right)$, the $\mathrm{pH}$ increased further after aeration to a final $\mathrm{pH}$ that was about the same as the treatment without $\mathrm{NaOH}$ : about 9.6-9.7 vs. 9.5, respectively (Table 3). The $\mathrm{N}$ recovery process with aeration plus precipitation significantly reduced the total alkalinity in the liquid. It was reduced from $11,400 \pm 35 \mathrm{mg} \mathrm{L}^{-1}$ to $2,520 \pm 108 \mathrm{mg} \mathrm{L}^{-1}$ 
at a rate of $3.9 \mathrm{~g}$ total alkalinity consumed per $\mathrm{g}$ of $\mathrm{N}$ removed from the liquid.

From Eq. 1, it may be shown that $3.57 \mathrm{~g}$ of alkalinity as $\mathrm{CaCO}_{3}$ are destroyed per $\mathrm{g}$ of $\mathrm{NH}_{3}-\mathrm{N}$ removed by the membrane system. Liu et al. (2015) indicated that in $\mathrm{Mg}^{2+}-\mathrm{Ca}^{2+}-\mathrm{NH}_{4}{ }^{+}-\mathrm{PO}_{4}{ }^{3-}$ systems, the bicarbonate alkalinity plays an important role in phosphate removal because it decreases the removal rate of phosphate in the precipitate reaction.

The $\mathrm{NH}_{4}{ }^{+}$concentration in the manure was monitored daily and the target level of removal of $>90 \%$ was reached at about 5 to 6 days of treatment (Fig. 3). At that time, the liquid was transferred to a settling vessel to harvest the suspended $\mathrm{P}$ solids. In all three treatments, the total $\mathrm{P}$ recovered by the system was high, approximately $>99 \%$, as well as the total $\mathrm{N}$ recovered of approximately $>88 \%$ (Table 2, configuration 2). During the $\mathrm{N}$ recovery period, $\mathrm{NH}_{4}{ }^{+}$concentration in the wastewater was reduced $>93 \%$ from an initial $2350 \pm 92 \mathrm{mg} \mathrm{N} \mathrm{L}^{-1}$ to $<170 \mathrm{mg} \mathrm{N} \mathrm{L}^{-}$ ${ }^{1}$ at 5-6 days. At the same time, the $\mathrm{NH}_{4}{ }^{+}$concentration in the stripping solution increased to approximately $12,000 \mathrm{mg} \mathrm{N} \mathrm{L}^{-1}$ (Fig. 3), about 5 times the concentration of the influent manure. The $\mathrm{NH}_{4}{ }^{+}$removal efficiency (93-97\%, Fig. A.2.) and the $\mathrm{NH}_{4}{ }^{+}$recovery efficiency $(92-93 \%$, Table 3$)$ obtained in the ammoniaseparation tank after 5-6 days were consistent among the three treatments. However, the rate of $\mathrm{NH}_{4}{ }^{+}$removal observed during the first 24 hours was different. This rate was faster in the alkali amended treatments. For instance, in the first 24 hours, $270 \mathrm{mg} \mathrm{NH}_{4}-\mathrm{N} \mathrm{L}^{-1}$ were removed from liquid manure in the $0 \mathrm{mmol} \mathrm{NaOH} \mathrm{L}^{-}$ ${ }^{1}$ treatment (aeration only), compared to $\mathrm{NH}_{4}{ }^{+}$removals of 650 and $830 \mathrm{mg} \mathrm{NH}_{4}-\mathrm{N}$ $\mathrm{L}^{-1}$ the 2.7 and $117 \mathrm{mmol} \mathrm{NaOH} \mathrm{L}^{-1}$ treatments (Fig. 3). 
[Figure 3]

The process reduced total P concentrations in the effluent about $91-95 \%$, from $446 \pm 7 \mathrm{mg} \mathrm{P} \mathrm{L}^{-1}$ to $<50 \mathrm{mg} \mathrm{P} \mathrm{L}^{-1}$ (Table 3). A schematic mass balance of the recovery of $\mathrm{N}$ and $\mathrm{P}$ (for the first case without alkali addition) is shown in Fig. 4 . The process provided quantitative recovery of the $\mathrm{P}$ in the solid form and yielded approximately $100 \%$ recovery. For $\mathrm{N}$, the combined process recovered approximately $91 \%$; approximately $8 \%$ of the $\mathrm{N}$ was recovered in the $\mathrm{P}$ precipitate and approximately $83 \%$ of the $\mathrm{N}$ was recovered in the $\mathrm{NH}_{4}{ }^{+}$concentrate with the gas-permeable membrane module. The addition of alkali to the process did not improve $\mathrm{N}$ or $\mathrm{P}$ recovery efficiencies. However, the alkali addition affected the amount of $\mathrm{N}$ recovered in the $\mathrm{P}$ precipitate, it decreased from approximately $8 \%$ to $3 \%$ (Table 2). It also affected the $\mathrm{P}_{2} \mathrm{O}_{5}$ grade and $\mathrm{P}: \mathrm{Mg}: \mathrm{N}$ molar ratios of the $\mathrm{P}$ product as discussed in the following section. Overall, results of nutrient recovery obtained with configuration 2 indicate that efficient $\mathrm{N}$ and $\mathrm{P}$ recovery can also be obtained using the gas-permeable system and simultaneous $\mathrm{P}$ precipitation with $\mathrm{MgCl}_{2}$ in a single operation.

[Figure 4]

\subsection{Composition of the recovered phosphorus products.}

Nearly $100 \%$ of the total $\mathrm{P}$ removed from the liquid manure using the process (configurations 1 and 2) was recovered in the precipitated solids, as shown in the solid analyses (Table 4). The precipitate settled readily within 0.5 hours, and it was concentrated to a volume that ranged from 15 to $27 \mathrm{~mL}$ per $\mathrm{L}$ of 
liquid treated. Although the $\mathrm{P}$ recovery using the gas-permeable membrane process with Mg precipitating compounds was consistently high in all configuration and treatments, the chemical composition of the P precipitate obtained varied with system configuration and the treatments (Tables 4 and 5 ).

The process with configuration 1 - which removed $70 \%$ of the $\mathrm{NH}_{3}$ from the liquid before $\mathrm{Mg}^{2+}$ addition - produced high quality $\mathrm{P}$ materials with surprisingly high $\mathrm{P}$ and $\mathrm{Mg}$ content and with low concentration of $\mathrm{N}$ : approximately $46 \% \mathrm{P}_{2} \mathrm{O}_{5}$ (20\% P) and approximately $17 \% \mathrm{Mg}$, and $1.8 \% \mathrm{~N}$ (Table 5). Calcium and $\mathrm{K}$ content were generally low, $0.4 \%$ and $1.7 \%$, respectively, indicating that Caphosphates and K-phosphates were not important contributors to the precipitate. The precipitate composition was unchanged in the second treatment with additional $\mathrm{NaOH}$. In both treatments, the resulting molar ratio relative to $\mathrm{P}$ was approximately 1.0:1.1:0.2:0.0:0.1 for P:Mg: $\mathrm{N}: \mathrm{Ca}: \mathrm{K}$, respectively. The plant available $\mathrm{P}$ of the product was high, $>99 \%$ (Table 5). As a comparison, triple superphosphate contains $46 \% \mathrm{P}_{2} \mathrm{O}_{5}$ and phosphate rock mineral in the USA typically contains 27.5 to $37.9 \% \mathrm{P}_{2} \mathrm{O}_{5}$. For $\mathrm{Mg}$ phosphates, two potential forms that can precipitate in liquid systems that contain $\mathrm{Mg}^{2+}-\mathrm{NH}_{4}{ }^{+}-\mathrm{PO}_{4}{ }^{3-}$ and a high $\mathrm{Mg} / \mathrm{Ca}$ ratio are struvite and newberyite (Boistelle et al., 1983; Abbona et al., 1988; Muster et al., 2013). Struvite $\left(\mathrm{MgNH}_{4} \mathrm{PO}_{4} \cdot 6 \mathrm{H}_{2} \mathrm{O}\right)$ has approximately $29 \% \mathrm{P}_{2} \mathrm{O}_{5}, 9.9 \% \mathrm{Mg}$ and 5.7\% $\mathrm{N}$ composition and 1:1:1 P:Mg: $\mathrm{N}$ molar ratio. Newberyite $\left(\mathrm{MgHPO}_{4} \cdot 3 \mathrm{H}_{2} \mathrm{O}\right)$, a biomineral found in guano deposits, has approximately $40.8 \%$ $\mathrm{P}_{2} \mathrm{O}_{5}$ and $13.9 \% \mathrm{Mg}$ composition and 1:1 P:Mg molar ratio. The formation of one 
or the other depends on the $\mathrm{NH}_{3}$ concentration, solution strength, $\mathrm{pH}$ and time according to the following reactions for the formation of struvite (Eq. 4) and newberyite (Eq. 5):

$$
\begin{gathered}
\mathrm{Mg}^{2+}+\mathrm{H}_{2} \mathrm{PO}_{4}^{-}+\mathrm{NH}_{3} \rightarrow \mathrm{MgNH}_{4} \mathrm{PO}_{4}+\mathrm{H}^{+} \\
\mathrm{Mg}^{2+}+\mathrm{H}_{2} \mathrm{PO}_{4}^{-} \rightarrow \mathrm{MgHPO}_{4}+\mathrm{H}^{+}
\end{gathered}
$$

The composition of the precipitate obtained using configuration 1 is more similar to newberyite than struvite. It contained $46.3 \% \mathrm{P}_{2} \mathrm{O}_{5}\left(6.52 \mathrm{mmol} \mathrm{P} \mathrm{g}^{-1}\right)$, which is about $60 \%$ higher $\mathrm{P}$ grade than struvite $\left(29.0 \% \mathrm{P}_{2} \mathrm{O}_{5}, 4.07 \mathrm{mmol} \mathrm{P} \mathrm{g}^{-1}\right)$. These results showed that it is possible to produce $\mathrm{Mg}$ phosphates with high $\mathrm{P}_{2} \mathrm{O}_{5}$ content by removing the $\mathrm{NH}_{3}$ from the liquid with the gas-permeable membrane process. This is an important finding because recovered phosphates with high $\mathrm{P}_{2} \mathrm{O}_{5}$ content are more in line with mineral commercial fertilizers and favored by the fertilizer industry (Hao et al, 2013).

The process with configuration 2 - with a higher $\mathrm{NH}_{4}{ }^{+}$in liquid during $\mathrm{P}$ precipitation - produced P solids that were also high in available P ( $>98 \%$ plant available), but with lower P grade than configuration 1 (Tables 4 and 5). The first treatment with no alkali addition produced phosphates containing $26.4 \% \mathrm{P}_{2} \mathrm{O}_{5}$, $10 \% \mathrm{Mg}$ and $4.5 \% \mathrm{~N}$ (Table 5, configuration 2). The molar ratio was approximately 1.0:1.1:0.9:0.1:0.1 for P:Mg:N:Ca:K, respectively. The composition of this product was more similar to struvite (approximately $29 \% \mathrm{P}_{2} \mathrm{O}_{5}, 9.9 \% \mathrm{Mg}$, and $5.7 \% \mathrm{~N}$ ) than newberyite. Compared to typical process to produce struvite mineral that use $\mathrm{MgCl}_{2}$ and $\mathrm{NaOH}$ (Karunanithi et al., 2015), in this example aeration substituted for 
$\mathrm{NaOH}$ to increase the $\mathrm{pH}$ and produce the struvite type material that also contains $\mathrm{N}$. However, only about $8 \%$ of the $\mathrm{NH}_{3}$ is recovered in the $\mathrm{P}$ solids using the struvite route, and the majority of the $\mathrm{NH}_{3}$, approximately $83 \%$, being recovered with the gas-permeable membrane module, on a mass basis (Fig. 4).

With $\mathrm{NaOH}$ addition, the capture of $\mathrm{NH}_{3}$ by the gas-permeable membrane was more active during the first 24 hours and lowered the instant $\mathrm{NH}_{4}{ }^{+}$ concentration of the liquid manure when the P precipitate was being formed (Fig. 3). As a result, the precipitates produced had reduced $\mathrm{N}$ and higher $\mathrm{P}$ (Table 5, configuration 2). For example, at the higher $\mathrm{NaOH}$ rate $(117 \mathrm{mmol} \mathrm{NaOH})$, the $\mathrm{Mg}$ phosphates produced contained $37.2 \% \mathrm{P}_{2} \mathrm{O}_{5}, 14 \% \mathrm{Mg}$ and $2.2 \mathrm{~N}$, and molar ratio of approximately 1.0:1.1:0.3:0.1:0.2 for $\mathrm{P}: \mathrm{Mg}: \mathrm{N}: \mathrm{Ca}: \mathrm{K}$, respectively. The element composition approached the composition of newberyite type of material compared to struvite material. These results suggest that the removal of $\mathrm{NH}_{3}$ from the liquid by the gas-permeable membrane can influence the type of Mg phosphate being precipitated and that active $\mathrm{NH}_{3}$ capture with increased $\mathrm{pH}$ favors the formation of higher grade Mg phosphates approaching newberyite composition.

\section{Conclusions}

Phosphorus recovery of anaerobically digested swine wastewater via $\mathrm{MgCl}_{2}$ precipitation was enhanced by combining it with the recovery of $\mathrm{NH}_{3}$ through gaspermeable membranes and low-rate aeration. The low-rate aeration stripped the natural carbonate in the wastewater and increased $\mathrm{pH}$, which accelerated $\mathrm{NH}_{3}$ 
uptake in the gas-permeable membrane system and benefited $P$ recovery. The combined process provided quantitative (ca 100\%) P recovery efficiencies. With active $\mathrm{NH}_{3}$ extraction, the magnesium phosphates produced contained higher $\mathrm{P}_{2} \mathrm{O}_{5}$ grade (37-46\%) and lower N, similar to the composition of the biomineral newberyite.

\section{Acknowledgements}

This article is part of USDA-ARS Project 6082-13630-001-00D "Improvement of Soil Management Practices and Manure Treatment/Handling Systems of the Southern Coastal Plains." We acknowledge the field and laboratory assistance of William Brigman and Chris Brown, USDA-ARS, Florence, SC, and the field sampling assistance of Diana Rashash, North Carolina Extension Service/ North Carolina State University. Mention of trade names or commercial products in this article is solely for the purpose of providing specific information and does not imply recommendation or endorsement by the USDA.

\section{References}

Abbona, F., Lundager Madsen, H.E., Boistelle, R., 1988. The final phases of calcium and magnesium phosphates precipitated from solutions of high to medium concentration. J. Crystal Growth 89,592-602.

AOAC International. 2000. Official Methods of Analysis. $17^{\text {th }}$ Ed. AOAC Int., Gaithersburg, MD. 
APHA. 1998. Standard Methods for the Examination of Water and Wastewater, 20th ed. American Public Health Association, American Water Works Association, Water Environment Federation. Washington, DC.

ASTM, 2011. Standard Test Methods for Pore Size Characteristics of Membrane Filters by Bubble Point and Mean Flow Pore Test. ASTM F316-03. ASTM International. West Conshohocken, PA.

Boistelle, R., Abbona, F., Lundager Madsen, H.E., 1983. On the transformations of struvite into newberyite in aqueous systems. Phys. Chem. Minerals 9, 216-222.

Bonmati, A., Flotats, X., 2003. Air stripping of ammonia from pig slurry: characterization and feasibility as a pre-or post-treatment to mesophilic anaerobic digestion. Waste Management. 23, 261-272.

Burns R.T., Moody, L.B., Walker, F.R., Raman, D.R., 2001. Laboratory and in-situ reductions of soluble phosphorus in liquid swine waste slurries. Environmental Technology 22(11),1273-1278.

Desmidt, E., Ghyselbrecht, K., Zhang, Y., Pinoy, L., Van der Bruggen, B., Verstraete, W., Rabaey, K., Meesschaert, B., 2015. Global Phosphorus Scarcity and FullScale P-Recovery Techniques: A Review. Critical Reviews In Environmental Science And Technology 45 (4), 336-384.

Dube, P.J., Vanotti, M. B., Szogi, A. A., García-González, M. C., 2016. Enhancing recovery of ammonia from swine manure anaerobic digester effluent using gaspermeable membrane technology. Waste Management 49, 372-377.

EPA. 2014. National emission inventory-ammonia emissions from animal husbandry 
operations. U.S. Environmental Protection Agency. Retrieved from https://www3.epa.gov/ttnchie1/ap42/ch09/related/nh3inventorydraft_jan2004.pdf

Gallaher, R. N., Weldon, C.O., Boswell, F.C., 1976. A semiautomated procedure for total nitrogen in plant and soil samples. Soil Science Society of American Journal 40, $887-889$.

Garcia-Gonzalez, M.C., Vanotti, M.B., 2015. Recovery of ammonia from swine manure using gas-permeable membranes: Effect of waste strength and $\mathrm{pH}$. Waste Management $38,455-461$.

Garcia-Gonzalez, M.C., Vanotti, M.B., Szogi, A.A., 2015. Recovery of ammonia from swine manure using gas-permeable membranes: Effect of aeration. Journal of Environmental Management 152, 19-26.

Hao, X., Wang, C., van Loosdrecht, M.C.M., Hu, Y., 2013. Looking beyond struvite for P-recovery. Environ. Scie. Technol. 47, 4965-4966.

Karunanithi, R., Szogi, A.A., Bolan, N., Naidu, R., Loganathan, P., Hunt, P.G., Vanotti, M.B., Saint, C.P., Ok, Y.S., Krishnamoorthy, S. , 2015. Phosphorus recovery and reuse from waste streams. Advances in Agronomy 131, 173-250.

Kertész, Sz., Beszédes, S., László, Zs., Szabó, G., Hodúr, C., 2010. Nanofiltration and reverse osmosis of pig manure: Comparison of results from vibratory and classical modules. Desalination and Water Treatment 14(1-3), 233-238.

Keyzer, M., 2010. Towards a closed phosphorus cycle. De Economist 158, 411-425.

Kleinman, P.J.A., Sharpley, A.N., Withers, P.J.A., Bergström, L., Johnson, L.T., Doody, D.G., 2015. Implementing agricultural phosphorus science and 
management to combat eutrophication. Ambio 44(Suppl 2), 297-310. doi: $10.1007 / \mathrm{s} 13280-015-0631-2$

Liao, P.H., Chen, A., Lo, K.V., 1995. Removal of nitrogen from swine manure wastewaters by ammonia stripping. Bioresource Technology. 54, 17-20.

Liberti, L., Limoni, N., Lopez, A., Passino, R., Boari, G., 1986. The $10 \mathrm{~m}^{3} \mathrm{~h}^{-1} \mathrm{RIM}-$ NUT demonstration plant at West Bari for removing and recovering $\mathrm{N}$ and $\mathrm{P}$ from wastewater. Water Res. 20(6), 735-739.

Liu, X., Xiang, L., Song, Y., Feng Qian, F., Meng, X., 2015. The effects and mechanism of alkalinity on the phosphate recovery from anaerobic digester effluent using dolomite lime. Environ. Earth Sci. 73(9), 5067-5073.

Masse, L., Massé, D.I., Pellerin, Y., Dubreuil, J., 2010. Osmotic pressure and substrate resistance during the concentration of manure nutrients by reverse osmosis membranes. Journal of Membrane Science. 348, 28-33.

Milan, Z., Sanchez, E., Weiland, P., de Las Pozas, C., Borja, R., Mayari, R., Rovirosa, N., 1997. Ammonia removal from anaerobically treated piggery manure by ion exchange in columns packed with homoionic zeolite. Chemical Engineering Journal. 66(1), 65-71.

Muster, T.H., Douglas, G.B., Sherman, N., Seeber, A., Wright, N., Güzükara, Y., 2013. Towards effective phosphorus recycling from wastewater: Quantity and quality. Chemosphere 91, 676-684.

Nelson, N. O., Mikkelsen, R. L., Hesterberg, D. L., 2003. Stuvite precipitation in anaerobic swine lagoon liquid: effect of $\mathrm{pH}$ and $\mathrm{Mg}: \mathrm{P}$ ratio and determination of 
rate constant. Bioresource Technology 89, 229-236.

Technicon Instruments Corp., 1997. Individual/simultaneous determination of nitrogen and/or phosphorus in BD acid digests (dialyzer). Industrial method 33774W/B. Tarrytown, NY: Technicon Instruments Corp.

Szogi, A.A., Vanotti, M.B., Hunt, P.G., 2015. Phosphorus recovery from pig manure prior to land application. J. Environ Manage. 157,1-7.

Thorneby, L., Persson, K., Tragardh, G., 1999. Treatment of liquid effluents from dairy cattle and pigs using reverse osmosis, Journal of Agricultural Engineering Research; 73 (2): 159-170.

Uludag-Demirer, S., Demirer, G. N., Chen, S., 2005. Ammonia removal from anaerobically digested dairy manure by struvite precipitation. Process Biochemistry; 40: 3667-3674.

Vanotti, M. B., Szogi, A.A., Hunt, P.G., 2003. Extraction of soluble phosphorus from swine wastewater. Trans. ASAE 46(6), 1665-1674.

Vanotti, M.B., Szogi, A.A., Hunt, P. G., 2005. Wastewater treatment system. U.S. Patent No. 6,893,567. U.S. Patent and Trademark Office.

Vanotti, M.B., Szogi, A.A., Bernal, M.P., Martinez, J., 2009. Livestock waste treatment systems of the future: A challenge to environmental quality, food safety, and sustainability. OECD Workshop. Biores. Technol. 100(22), 5371-5373.

Vanotti, M.B., Szogi, A.A., 2015. Systems and methods for reducing ammonia emissions from liquid effluents and for recovering ammonia. U.S. Patent 9,005,333 B1. U.S. Patent and Trademark Office. 
Vanotti, M.B., Szogi, A.A., Dube, P.J., 2016. Systems and methods for recovering ammonium and phosphorus from liquid effluents. U.S. Patent Application 62/169,387. U.S. Patent and Trademark Office.

Westerman, P.W., Bowers, K.B., Zering, K.D., Adcock, M.E., 2008. Phosphorus recovery from covered digester effluent with a continuous-flow struvite crystallizer. Proc. 2008 ASABE Annual International Meeting. Paper No. 083892. ASABE, St. Joseph, Michigan, pp.1-13.

Zarebska, A., Romero Nieto, D., Christensen, K.V., Fjerbaek Sotoft, L., Norddahl, B., 2015. Ammonium fertilizers production from manure: a critical review. Critical Reviews in Environmental Science and Technology. 45, 1469-1521.

\section{Figure Captions}

Figure 1. Schematic showing the basic configuration of the process used to remove ammonia and phosphorus from liquid swine manure.

Figure 2. Removal and recovery of ammonia using gas-permeable membranes in experiment 1. The error bars are standard deviation of duplicate experiments.

Figure 3. Removal and recovery of ammonia using gas-permeable membranes and aeration in experiment 2 (configuration 2) . A) Treatment $1-0 \mathrm{mmol} / \mathrm{L} \mathrm{NaOH}$, B) Treatment $2-2.67 \mathrm{mmol} / \mathrm{L} \mathrm{NaOH}, \mathrm{C})$ Treatment $3-117 \mathrm{mmol} / \mathrm{L} \mathrm{NaOH}$. The error bars are standard deviation of duplicate experiments.

Figure 4. Schematic showing the mass balance of $N$ and $P$ in nutrient recovery system for configuration 2, treatment without alkali addition. Mass balances for all treatments are shown in table 2.

\section{Appendix - Figure Captions}

Fig. A.1. Experimental device for $\mathrm{NH}_{4}{ }^{+}$capture from manure using gas-permeable membranes and low-level aeration to increase manure $\mathrm{pH}$

Fig. A.2. Ammonia and phosphorus concentrations of influent and treated effluents from configurations 1 and 2 . The error bars are standard deviation of duplicate 
experiments.

Appendix

[Place Fig. A.1]

[Place Fig. A.2] 
Table 1. Removal and recovery of ammonia and phosphorus from liquid swine manure using gas-permeable membranes magnesium chloride precipitation in configuration $1^{\text {ab }}$

\begin{tabular}{|c|c|c|c|c|c|c|c|c|c|}
\hline $\begin{array}{l}\mathrm{MgCl}_{2} \\
\text { Applied } \\
\left(\mathrm{mmol} \mathrm{L}^{-1}\right)\end{array}$ & $\begin{array}{c}\mathrm{NaOH} \\
\text { Applied } \\
\left(\mathrm{mmol} \mathrm{L}^{-1}\right)\end{array}$ & $\mathrm{pH}$ & $\begin{array}{c}\text { Total } \\
\text { Alkalinity } \\
\left(\mathrm{mg} \mathrm{CaCO}_{3}\right. \\
\left.\mathrm{L}^{-1}\right) \\
\end{array}$ & $\begin{array}{c}\mathrm{NH}_{4}-\mathrm{N}(\mathrm{mg} \\
\left.\mathrm{L}^{-1}\right)\end{array}$ & $\begin{array}{l}\text { Total P } \\
\left(\mathrm{mg} \mathrm{L}^{-1}\right)\end{array}$ & $\begin{array}{c}\mathrm{NH}_{4}-\mathrm{N} \\
\text { Removal } \\
\text { Efficiency } \\
(\%) \\
\end{array}$ & $\begin{array}{c}P \\
\text { Removal }^{\text {efficiency }}{ }^{d} \\
(\%)\end{array}$ & $\begin{array}{c}\mathrm{NH}_{4}-\mathrm{N} \\
\text { Recovery } \\
\text { Efficiency }^{\mathrm{e}} \\
(\%)\end{array}$ & $\begin{array}{c}P \\
\text { Recovery } \\
\text { Efficiency }^{f} \\
(\%) \\
\end{array}$ \\
\hline \multicolumn{10}{|l|}{ Influent } \\
\hline 0 & -- & $8.36(0.01)$ & $11400(35)$ & 2300 (110) & 446 (7) & -- & -- & -- & -- \\
\hline \multicolumn{10}{|c|}{ Effluent after ammonia removal $^{\mathrm{g}}$} \\
\hline 0 & -- & $9.38(0.06)$ & $6230(239)$ & $696(56)$ & $462(1)$ & 69.7 & -- & 99.9 & -- \\
\hline \multicolumn{10}{|c|}{ Effluent after phosphorus precipitation } \\
\hline 16.4 & 0 & $8.45(0.00)$ & $4800(20)$ & $574(0)$ & $21(1)$ & 75.0 & 95.3 & 94.9 & 99.1 \\
\hline 16.4 & 9.5 & $9.19(0.01)$ & $4440(7)$ & $537(13)$ & $12(2)$ & 76.6 & 97.3 & 92.8 & 97.4 \\
\hline
\end{tabular}

a. In Configuration 1, the precipitating chemicals were added after $\mathrm{NH}_{4}{ }^{+}$was substantially removed from the manure with gas-permeable membrane module.

b. $\quad 1.5 \mathrm{~L}$ manure in a $2 \mathrm{~L}$ vessel, using $250 \mathrm{~mL} 1 \mathrm{~N} \mathrm{H}_{2} \mathrm{SO}_{4}$ of acidic solution in the concentrator tank (recirculation rate of $4 \mathrm{~mL} \mathrm{~min}{ }^{-1}$ ) and membrane tubing length $=0.6 \mathrm{~m}$ (area $\left.=194 \mathrm{~cm}^{2}\right)$. Aeration rate $=180 \mathrm{~mL} \mathrm{~min}^{-1}\left(0.12 \mathrm{~L}\right.$ air L manure $\left.\mathrm{minute}^{-1}\right)$. Data are average and std. dev. of duplicate reactors.

c. $\quad \mathrm{NH}_{4}-\mathrm{N}$ removal efficiency $=\left(\mathrm{NH}_{4}-\mathrm{N}\right.$ removed from manure/initial $\mathrm{NH}_{4}-\mathrm{N}$ in manure $) \times 100$.

d. $P$ removal efficiency $=(P$ removed from manure/initial $P$ in manure $) \times 100$.

e. $\quad \mathrm{NH}_{4}-\mathrm{N}$ recovery efficiency $=\left[\left(\mathrm{NH}_{4}-\mathrm{N}\right.\right.$ recovered by membrane in concentration tank $+\mathrm{NH}_{4}-\mathrm{N}$ recovered as solid in the precipitate $) / \mathrm{NH}_{4}-\mathrm{N}$ removed from manure)] $\times 100$. Recovered $\mathrm{N}$ shown table 2 .

f. $\quad P$ recovery efficiency $=(P$ recovered in the precipitated solid/P removed from manure $) \times 100 . \quad$ Recovered $P$ shown in table 2.

g. Ammonia removal step after 2 -days when about $70 \%$ of $\mathrm{N}$ was removed. 
Table 2. Mass balances of the recovery of ammonia and phosphorus from digested swine effluent using gas-permeable membrane module and chemical precipitation $^{a}$

\begin{tabular}{|c|c|c|c|c|c|c|c|c|c|}
\hline \multirow[b]{2}{*}{ Configuration } & \multirow[b]{2}{*}{$\begin{array}{l}\mathrm{MgCl}_{2} \\
\text { Applied }\end{array}$} & \multirow[b]{2}{*}{$\begin{array}{c}\mathrm{NaOH} \\
\text { Applied }\end{array}$} & \multirow[b]{2}{*}{ Nutrient } & Mass Inflow & \multicolumn{4}{|c|}{ Mass Outflow } & \multirow[b]{2}{*}{$\begin{array}{c}\text { Total } \\
\text { Recovered }^{\mathrm{c}}\end{array}$} \\
\hline & & & & Influent & $\begin{array}{c}\text { Recovered in } \\
\text { Solid } \\
\text { Precipitate }\end{array}$ & $\begin{array}{c}\text { Recovered by } \\
\text { Membrane }\end{array}$ & Effluent & Unaccounted $^{\mathrm{b}}$ & \\
\hline & $\mathrm{mmol} \mathrm{L}^{-1}$ & $\mathrm{mmol} \mathrm{L}^{-1}$ & & \multicolumn{6}{|c|}{$\mathrm{mg}$ (\% of initial) } \\
\hline \multirow[t]{2}{*}{1} & 16.4 & 0 & $\mathrm{~N}$ & $2300(100 \%)$ & $37(1.6 \%)$ & $1600(69.6 \%)$ & $574(25.0 \%)$ & $87(3.8 \%)$ & $1630(71.2 \%)$ \\
\hline & & & $P$ & $446(100 \%)$ & 421 (94.4\%) & $0(0.0 \%)$ & 21 (4.7\%) & 4 (0.9\%) & 421 (94.4\%) \\
\hline \multirow[t]{2}{*}{1} & 16.4 & 9.5 & $\mathrm{~N}$ & 2300 (100\%) & 35 (1.5\%) & 1600 (63.3\%) & 537 (23.4\%) & $126(5.5 \%)$ & 1630 (71.1\%) \\
\hline & & & $P$ & $446(100 \%)$ & 423 (94.8\%) & $0(0.0 \%)$ & $12(2.7 \%)$ & $11(2.5 \%)$ & $423(94.8 \%)$ \\
\hline \multirow[t]{2}{*}{$2^{d}$} & 16.4 & 0 & $\mathrm{~N}$ & $2350(100 \%)$ & $184(7.8 \%)$ & $1950(82.8 \%)$ & $69(2.9 \%)$ & $152(6.5 \%)$ & $2130(90.6 \%)$ \\
\hline & & & $P$ & $446(100 \%)$ & 472 (105.9\%) & 0 (0.0\%) & $24(5.4 \%)$ & $0(0.0 \%)$ & 472 (105.9\%) \\
\hline \multirow[t]{2}{*}{2} & 16.4 & 2.7 & $\mathrm{~N}$ & 2350 (100\%) & $104(4.4 \%)$ & 1970 (83.6\%) & 157 (6.7\%) & $126(5.3 \%)$ & $2070(88.0 \%)$ \\
\hline & & & $P$ & $446(100 \%)$ & 441 (98.8\%) & $0(0.0 \%)$ & $26(5.8 \%)$ & $0(0.0 \%)$ & 441 (98.8\%) \\
\hline \multirow[t]{2}{*}{2} & 16.4 & 117 & $\mathrm{~N}$ & 2350 (100\%) & 68 (2.9\%) & $2100(89.3 \%)$ & 163 (6.9\%) & $0(0.0 \%)$ & 2170 (92.2\%) \\
\hline & & & $\mathrm{P}$ & $446(100 \%)$ & $500(112.0 \%)$ & $0(0.0 \%)$ & 41 (9.2\%) & $0(0.0 \%)$ & $500(112.0 \%)$ \\
\hline
\end{tabular}

a. Mass balances based on a per liter (L) influent basis.

b. Unaccounted $=$ Influent - (recovered in solid precipitate + recovered by membrane + effluent).

c. Total recovered $=$ (Recovered in solid precipitate + recovered by membrane)/Influent $\times 100$.

d. Mass balance for this case shown also in Fig. 4. 
Table 3. Removal and recovery of ammonia and phosphorus from liquid swine manure using gas-permeable membranes magnesium chloride precipitation in configuration $2^{\mathrm{ab}}$

\begin{tabular}{|c|c|c|c|c|c|c|c|c|c|}
\hline $\begin{array}{r}\mathrm{MgCl}_{2} \\
\text { Applied } \\
\left(\mathrm{mmol} \mathrm{L}^{-1}\right)\end{array}$ & $\begin{array}{c}\mathrm{NaOH} \\
\text { Applied } \\
\left(\mathrm{mmol} \mathrm{L}^{-1}\right)\end{array}$ & $\mathrm{pH}$ & $\begin{array}{c}\text { Total } \\
\text { Alkalinity } \\
\left(\mathrm{mg} \mathrm{CaCO}_{3}\right. \\
\left.\mathrm{L}^{-1}\right)\end{array}$ & $\begin{array}{c}\mathrm{NH}_{4}-\mathrm{N} \\
\left(\mathrm{mg} \mathrm{L}^{-1}\right)\end{array}$ & $\begin{array}{l}\text { Total P } \\
\left(\mathrm{mg} \mathrm{L}^{-1}\right)\end{array}$ & $\begin{array}{c}\mathrm{NH}_{4}-\mathrm{N} \\
\text { Removal } \\
\text { Efficiency } \\
(\%)\end{array}$ & $\begin{array}{l}\text { P Removal } \\
\text { Efficiency }^{d} \\
(\%)\end{array}$ & $\begin{array}{c}\mathrm{NH}_{4}-\mathrm{N} \\
\text { Recovery } \\
\text { Efficiency } \\
(\%)\end{array}$ & $\begin{array}{c}\text { P } \\
\text { Recovery } \\
\text { Efficiency } \\
(\%) \\
\end{array}$ \\
\hline \multicolumn{10}{|l|}{ Influent } \\
\hline 0 & -- & $8.36(0.01)$ & $11400(35)$ & $2350(92)$ & $446(7)$ & -- & -- & -- & -- \\
\hline \multicolumn{10}{|c|}{ Effluent after ammonia removal and phosphorus precipitation } \\
\hline 16.4 & 0 & $9.47(0.01)$ & $2520(108)$ & $69(55)$ & $24(2)$ & 97.1 & 94.6 & 93.3 & 111.9 \\
\hline 16.4 & 2.7 & $9.56(0.02)$ & $2600(207)$ & $157(86)$ & $26(8)$ & 93.3 & 94.2 & 93.4 & 104.9 \\
\hline 16.4 & 117 & $9.69(0.21)$ & $5310(16)$ & $163(51)$ & $41(7)$ & 93.1 & 90.8 & 92.0 & 123.3 \\
\hline
\end{tabular}

a. In Configuration 2, the precipitating chemicals were added into the ammonia separation tank at the start of $\mathrm{NH}_{4}{ }^{+}$removal from the manure with the gas-permeable membrane module.

b. $1.5 \mathrm{~L}$ manure in a $2 \mathrm{~L}$ vessel, using $250 \mathrm{~mL} 1 \mathrm{~N} \mathrm{H}_{2} \mathrm{SO}_{4}$ of acidic solution in the concentrator tank (recirculation rate of $4 \mathrm{~mL} \mathrm{~min}^{-1}$ ) and membrane tubing length $=0.6 \mathrm{~m}$ (area $=194 \mathrm{~cm}^{2}$ ). Aeration rate $=180 \mathrm{~mL} \mathrm{~min}^{-1}\left(0.12 \mathrm{~L}\right.$ air L manure ${ }^{-1}$ minute ${ }^{-1}$ ). Data are average (and std. dev.) of duplicate reactors.

c. $\quad \mathrm{NH}_{4}-\mathrm{N}$ removal efficiency $=\left(\mathrm{NH}_{4}-\mathrm{N}\right.$ removed from manure/initial $\mathrm{NH}_{4}-\mathrm{N}$ in manure $) \times 100$.

d. $P$ removal efficiency $=(P$ removed from manure/initial $P$ in manure $) \times 100$.

e. $\quad \mathrm{NH}_{4}-\mathrm{N}$ recovery efficiency $=\left[\left(\mathrm{NH}_{4}-\mathrm{N}\right.\right.$ recovered by membrane in concentration tank $+\mathrm{NH}_{4}-\mathrm{N}$ recovered as solid in the precipitate $) / \mathrm{NH}_{4}-\mathrm{N}$ removed from manure)] $\times 100$.

f. $\quad$ P recovery efficiency $=(P$ recovered in the precipitated solid/P removed from manure $) \times 100$. 
Table 4. Phosphorus content and recovery in solids produced from liquid manure using gas-permeable membranes and $\mathrm{MgCl}_{2} \mathrm{precipitation}^{\mathrm{a}}$

\begin{tabular}{|c|c|c|c|c|c|c|c|c|}
\hline \multirow{2}{*}{ Configuration } & \multirow{2}{*}{$\begin{array}{l}\mathrm{MgCl}_{2} \text { Added } \\
\left(\mathrm{mmol} \mathrm{L}^{-1}\right)\end{array}$} & \multirow{2}{*}{$\begin{array}{l}\mathrm{NaOH} \text { Added } \\
\left(\mathrm{mmol} \mathrm{L}^{-1}\right)\end{array}$} & \multirow{2}{*}{$\begin{array}{l}\text { Precipitate } \\
\text { Volume Produced } \\
\text { per } L \text { of Liquid } \\
\text { Treated }(\mathrm{mL})\end{array}$} & \multirow{2}{*}{$\begin{array}{l}\text { Dewatered Solids } \\
\text { Produced per L of } \\
\text { Liquid Treated (g) }\end{array}$} & \multicolumn{2}{|c|}{$\begin{array}{c}\text { Phosphorus Content in } \\
\text { Solids }\end{array}$} & \multirow{2}{*}{$\begin{array}{l}\text { P Recovered in } \\
\text { Precipitate per } \\
\text { L of Liquid } \\
\text { Treated (mg) }\end{array}$} & \multirow{2}{*}{$\begin{array}{c}\text { P Recovery } \\
\text { Efficiency }^{c} \\
(\%)\end{array}$} \\
\hline & & & & & $\% \mathrm{P}$ & $\% \mathrm{P}_{2} \mathrm{O}_{5}{ }^{\mathrm{b}}$ & & \\
\hline 1 & 16.4 & 9.5 & $15.7(0.1)$ & $2.06(0.00)$ & $20.6(0.1)$ & $47.2(0.2)$ & 423 & 97.4 \\
\hline 2 & 16.4 & 0 & $25.5(0.3)$ & $4.11(0.09)$ & $11.5(0.9)$ & $26.4(2.0)$ & 472 & 112.9 \\
\hline 2 & 16.4 & 2.7 & $26.8(2.6)$ & $3.53(0.19)$ & $12.5(3.4)$ & $28.6(7.9)$ & 441 & 104.9 \\
\hline
\end{tabular}

a. Data are average (and std. dev.) of duplicate reactors. $\%=\mathrm{g}$ per $100 \mathrm{~g}$.

b. $\mathrm{P}_{2} \mathrm{O}_{5}=\mathrm{P} \times 2.2951$.

c. $\quad P$ recovery efficiency $=(P$ recovered in precipitate per $L$ of manure treated $/ P$ removed from manure $) \times 100$. $P$ removed from manure $=I n f l u e n t ~-$ effluent after phosphorus precipitation (Tables 1 and 3 ). 
Table 5. Composition of the solid precipitate produced from liquid swine manure using gas-permeable membranes and aeration to recover ammonia and precipitation of magnesium phosphates using $\mathrm{MgCl}_{2}{ }^{\mathrm{a}}$

\begin{tabular}{ccccccccc}
\hline Configuration & $\begin{array}{c}\mathrm{MgCl}_{2} \\
\text { Applied } \\
\left(\mathrm{mmol} \mathrm{L}^{-1}\right)\end{array}$ & $\begin{array}{c}\mathrm{NaOH} \\
\text { Applied } \\
\left(\mathrm{mmol} \mathrm{L}^{-1}\right)\end{array}$ & $\begin{array}{c}\mathrm{P}_{2} \mathrm{O}_{5}{ }^{\mathrm{b}} \\
(\%)\end{array}$ & $\begin{array}{c}\mathrm{N} \\
(\%)\end{array}$ & $\begin{array}{c}\mathrm{Mg} \\
(\%)\end{array}$ & $\begin{array}{c}\mathrm{Ca} \\
(\%)\end{array}$ & $\begin{array}{c}\mathrm{K} \\
(\%)\end{array}$ & $\begin{array}{c}\text { Available } \\
\mathrm{P}_{2} \mathrm{O}_{5} \\
(\% \text { of total) }\end{array}$ \\
\hline 1 & 16.4 & 0 & $46.4(0.7)$ & $1.8(0.01)$ & $17.1(0.2)$ & $0.39(0.05)$ & $1.87(0.01)$ & $99.7(0.03)$ \\
1 & 16.4 & 9.5 & $47.2(0.2)$ & $1.7(0.01)$ & $17.6(0.3)$ & $0.32(0.07)$ & $1.88(0.07)$ & $99.9(0.00)$ \\
\hline 2 & 16.4 & 0 & $26.4(2.0)$ & $4.5(0.00)$ & $10.0(0.7)$ & $2.01(0.10)$ & $1.65(0.37)$ & $99.0(0.37)$ \\
2 & 16.4 & 2.7 & $28.6(7.9)$ & $2.9(0.95)$ & $13.1(0.4)$ & $5.00(2.43)$ & $3.58(2.58)$ & $98.4(0.61)$ \\
2 & 16.4 & 117 & $37.2(3.7)$ & $2.2(0.39)$ & $14.1(1.3)$ & $2.99(0.30)$ & $4.46(0.92)$ & $98.9(0.10)$ \\
\hline
\end{tabular}

a. Data are the mean (and SD) of two replicates. $\%=g$ per $100 \mathrm{~g}$ precipitate solids. For available $\mathrm{P}, \%=g$ per $100 \mathrm{~g} \mathrm{P}_{2} \mathrm{O}_{5}$. b. $\mathrm{P}_{2} \mathrm{O}_{5}=\mathrm{P} \times 2.2951$. 


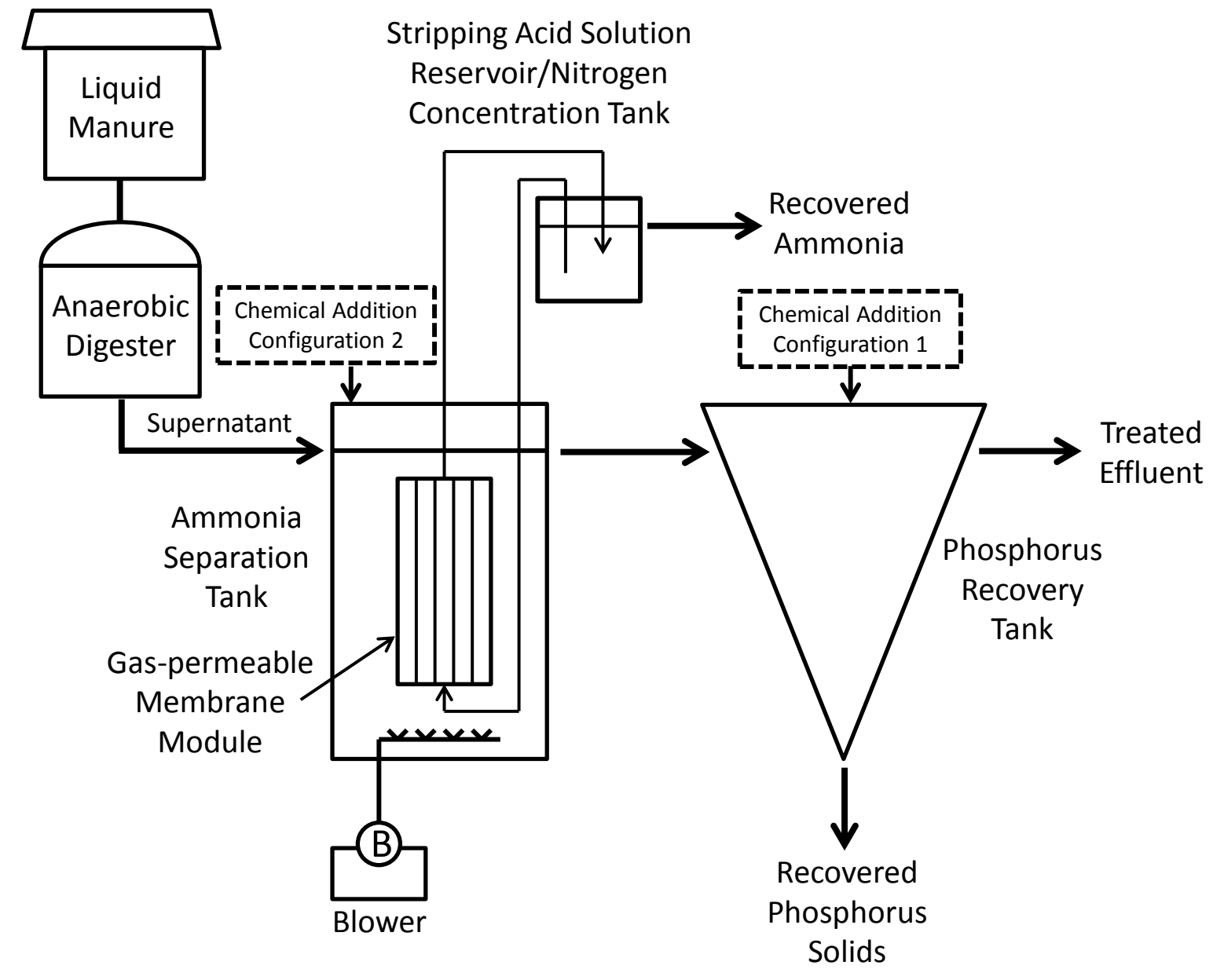

Figure 1. Schematic showing the basic configuration of the process used to remove ammonia and phosphorus from liquid swine manure. 


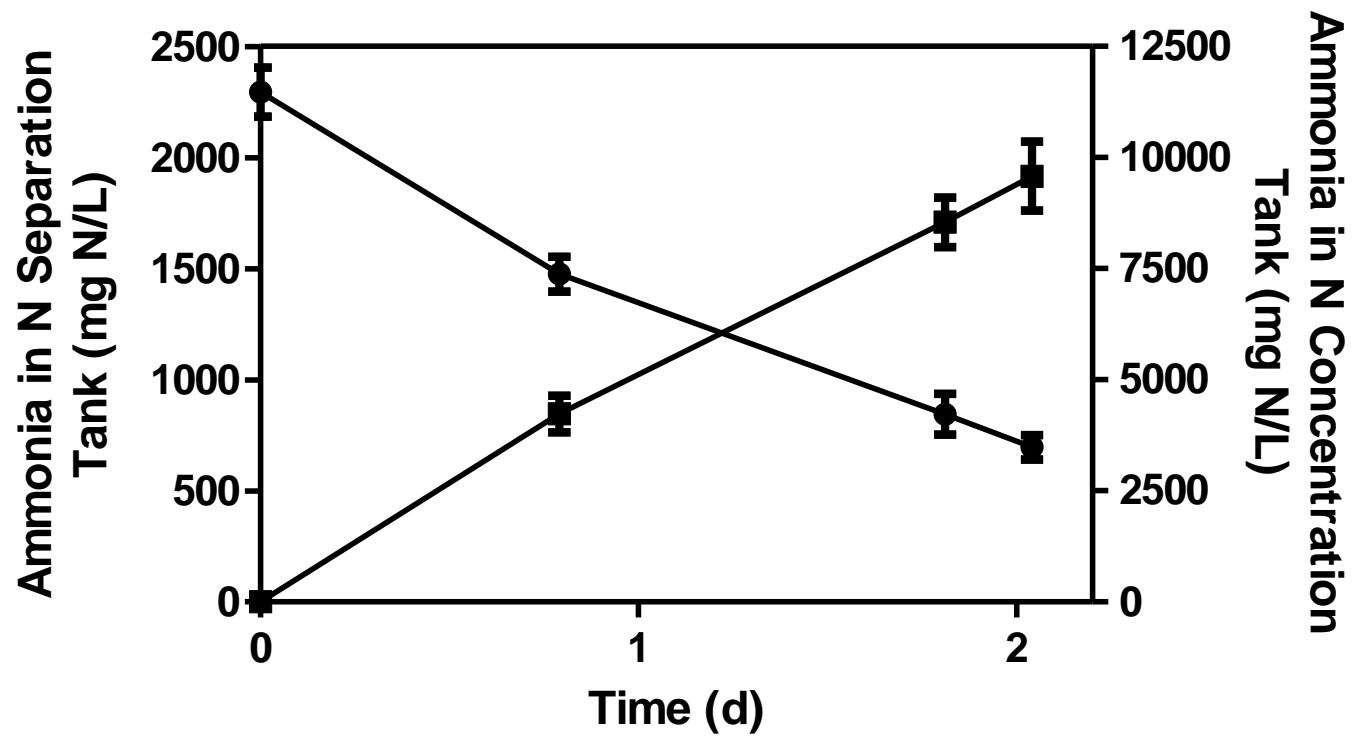

$\rightarrow$ Ammonia Separation Tank

$\rightarrow \mathrm{N}$ Concentration Tank

Figure 2. Removal and recovery of ammonia using gas-permeable membranes and aeration in experiment 1 (configuration 1). The error bars are standard deviation of duplicate experiments. 

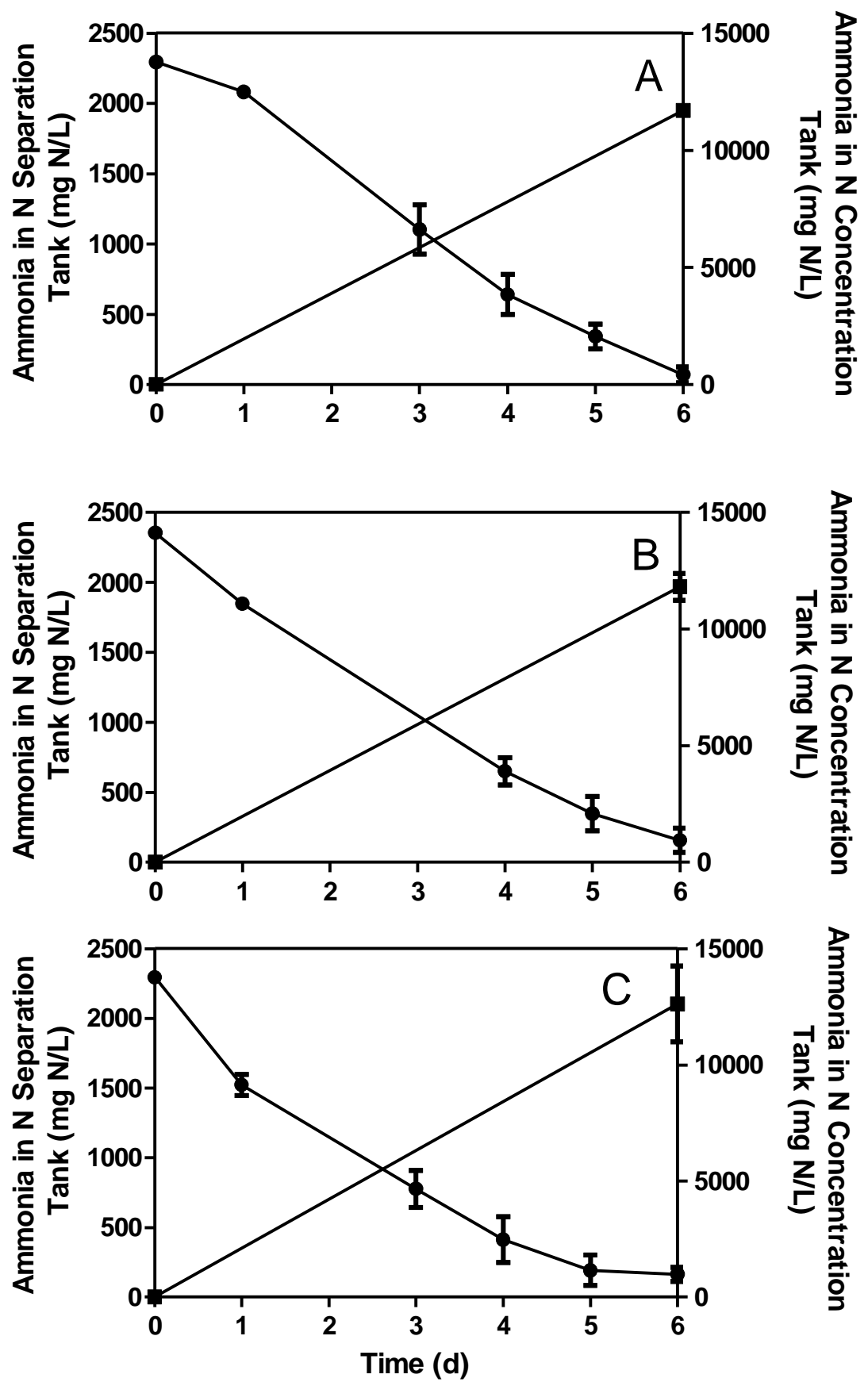

$\rightarrow$ Ammonia Separation Tank

$\rightarrow$ N Concentration Tank

Figure 3. Removal and recovery of ammonia using gas-permeable membranes and aeration in experiment 2 (configuration 2). A) Treatment $1-0 \mathrm{mmol} / \mathrm{L} \mathrm{NaOH}, \mathrm{B})$ Treatment $2-2.67 \mathrm{mmol} / \mathrm{L} \mathrm{NaOH}, \mathrm{C}$ ) Treatment 3 $117 \mathrm{mmol} / \mathrm{L} \mathrm{NaOH}$. The error bars are standard deviation of duplicate experiments. 
Configuration 2

$16.45 \mathrm{mmol} / \mathrm{L} \mathrm{MgCl}_{2}$

$0 \mathrm{mmol} / \mathrm{L} \mathrm{NaOH}$
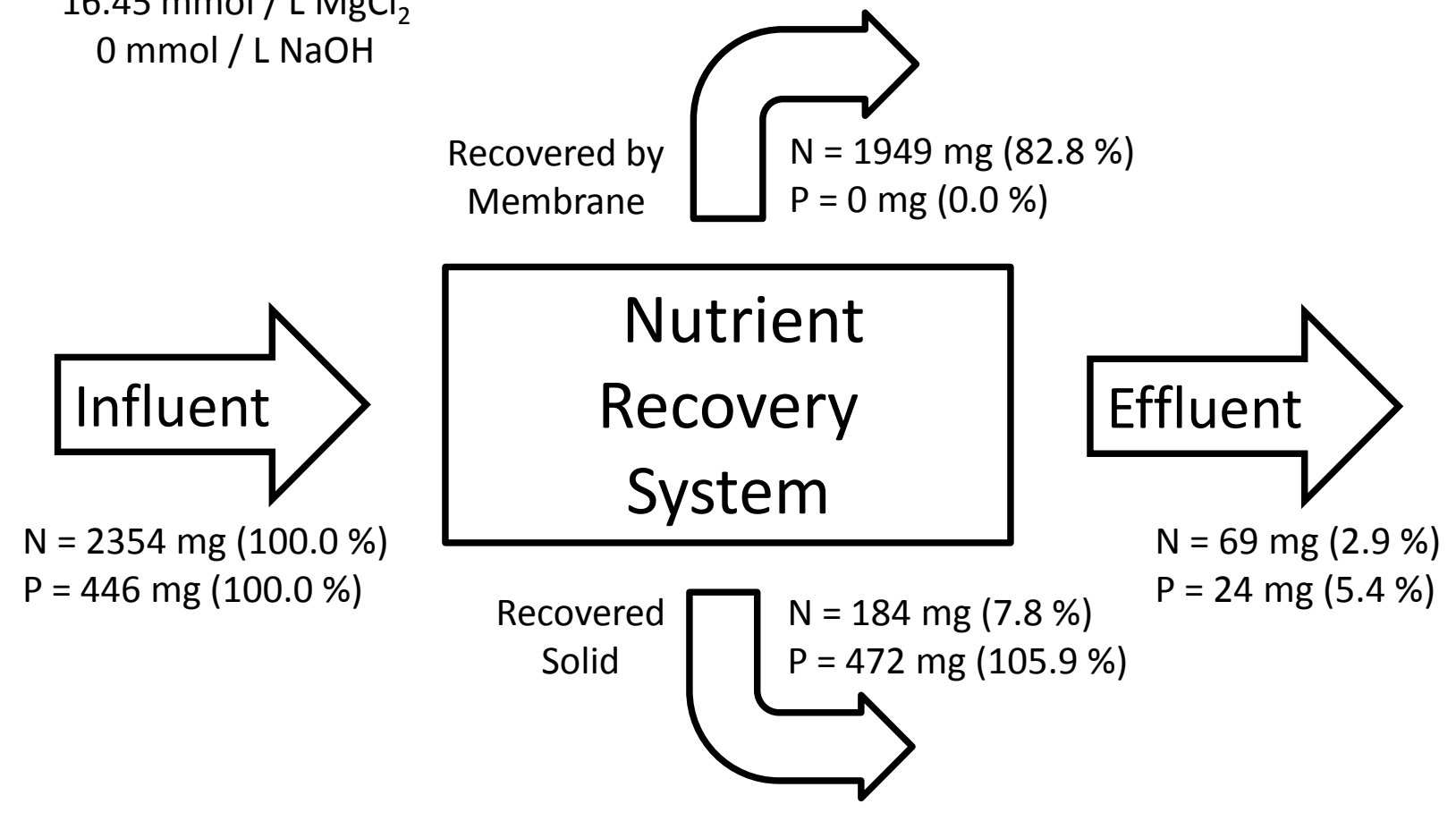

Figure 4. Schematic showing the mass balance of $\mathrm{N}$ and $\mathrm{P}$ in nutrient recovery system Configuration 2, without alkali addition. Mass balances for all treatments are shown in table 2 . 


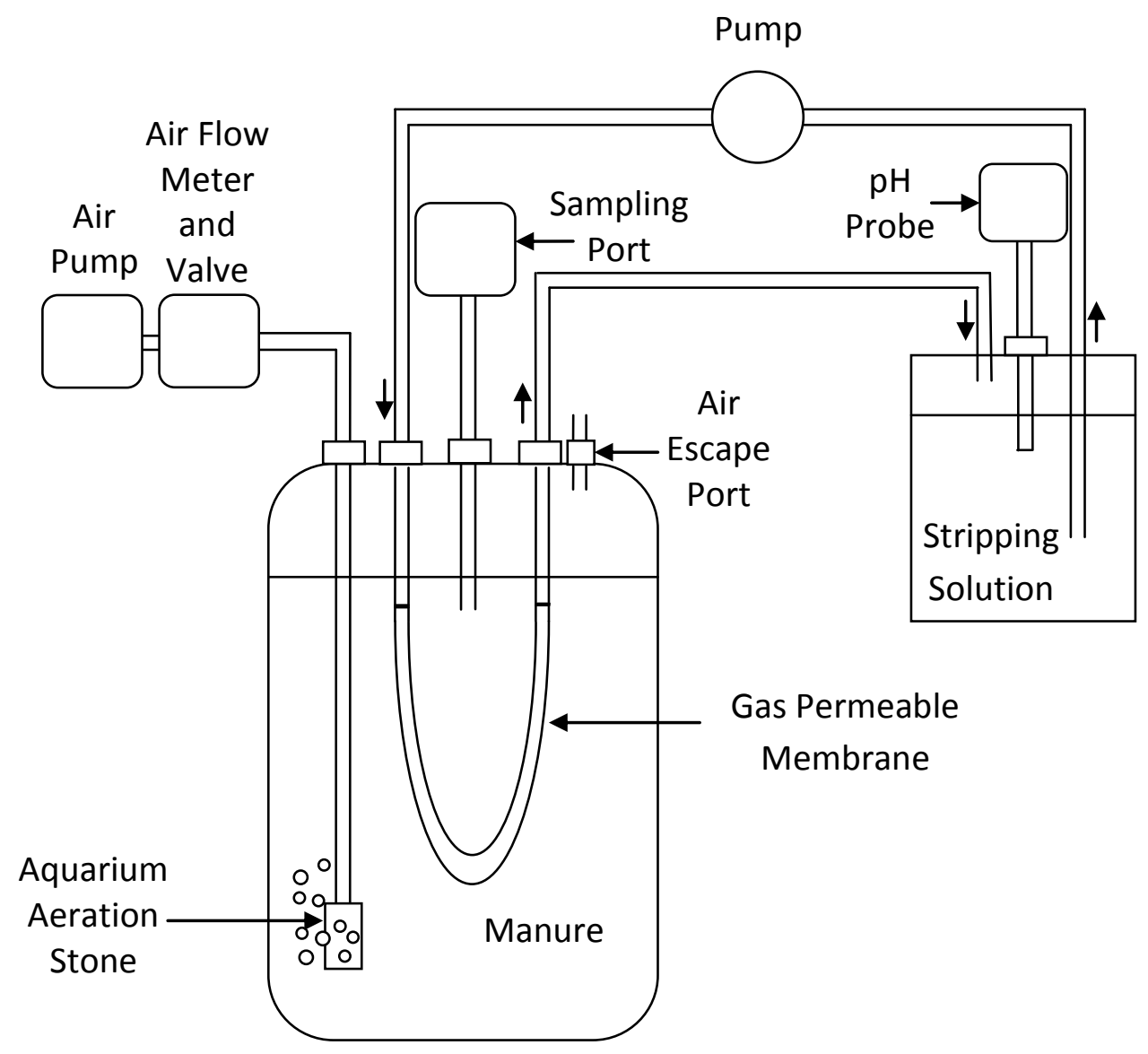

Figure A.1. Experimental device for $\mathrm{NH}_{4}{ }^{+}$capture from manure using gas-permeable membranes and low-level aeration to increase manure $\mathrm{pH}$. 


\section{Ammonia Removal}

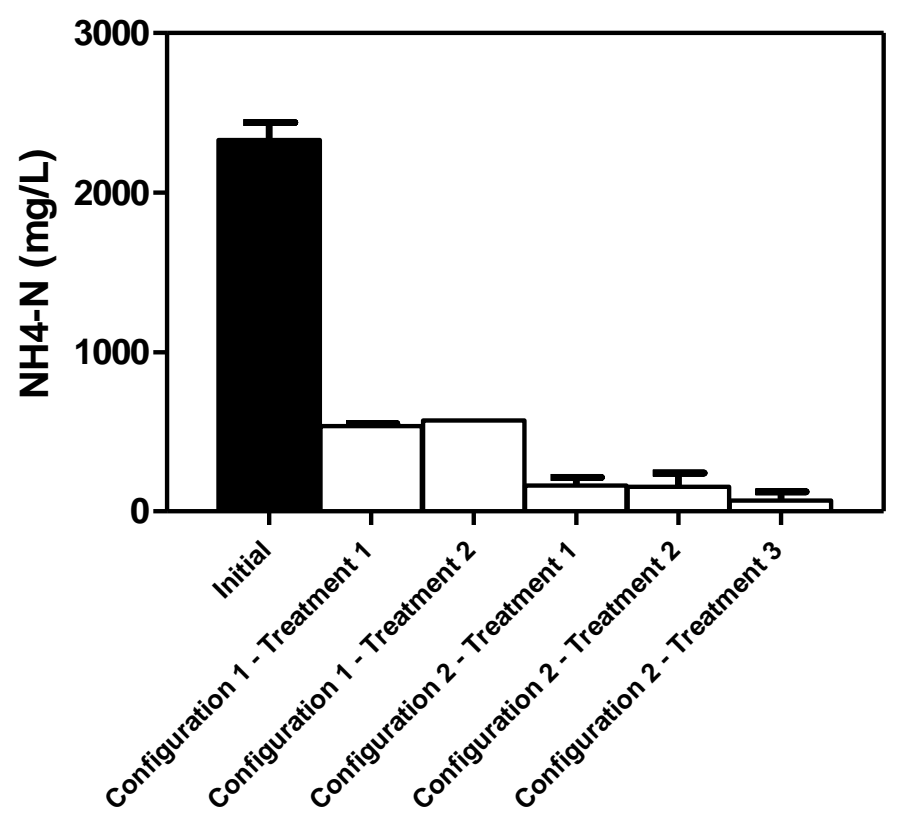

Phosphorus Removal

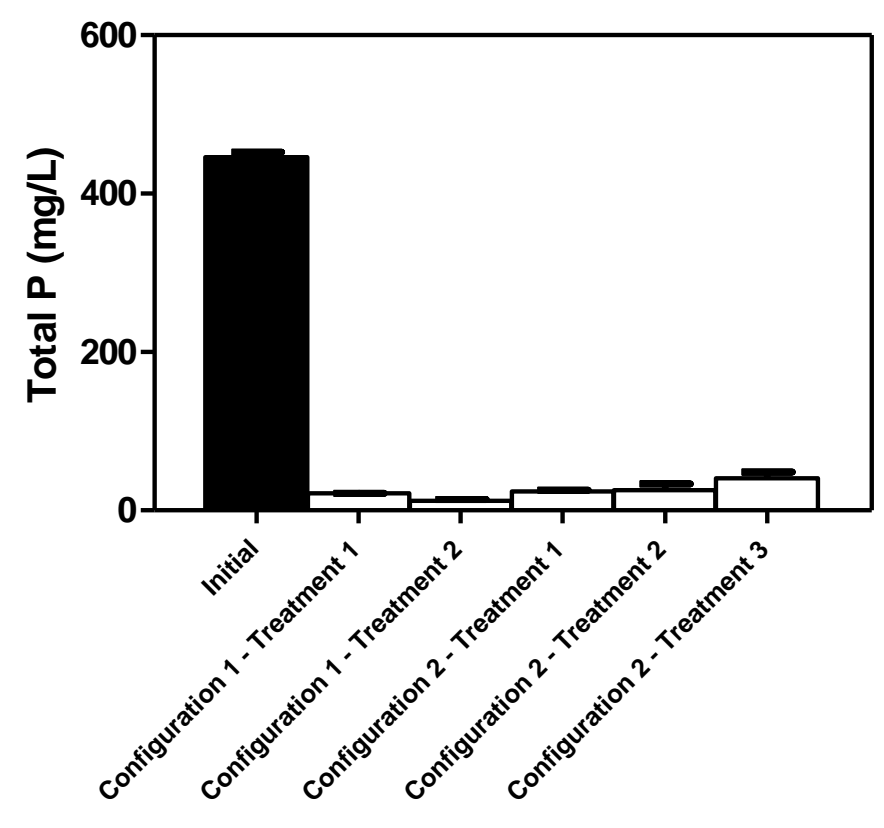

Figure A.2. Ammonia and phosphorus concentrations of influent and treated effluents from configurations 1 and 2 . The error bars are standard deviation of duplicate experiments. 
Digester Effluent $\mathrm{MgCl}_{2}$

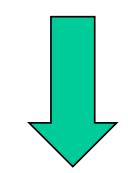

Gas-permeable Strip membrane

Solution $\left(\mathrm{H}^{+}\right)$
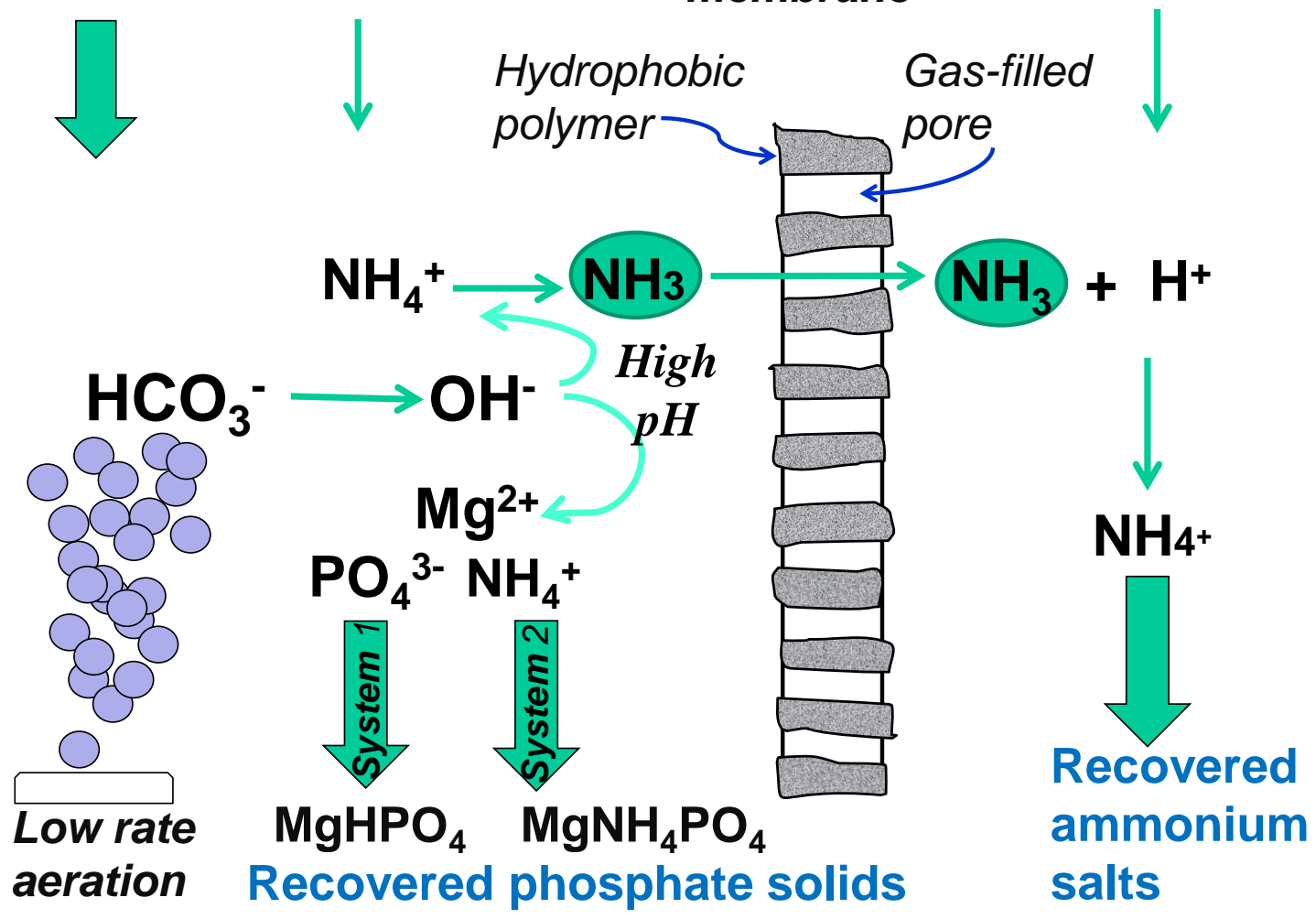
ammonium salts 